\title{
Modulation of Presynaptic Plasticity and Learning by the H-ras/Extracellular Signal-Regulated Kinase/Synapsin I Signaling Pathway
}

\author{
Steven A. Kushner, ${ }^{1 \star}$ Ype Elgersma, ${ }^{1,2 \star}$ Geoffrey G. Murphy, ${ }^{1}$ Dick Jaarsma, ${ }^{2}$ Geeske M. van Woerden, ${ }^{2}$ \\ Mohammad Reza Hojjati, ${ }^{2}$ Yijun Cui, ${ }^{1}$ Janelle C. LeBoutillier, ${ }^{3}$ Diano F. Marrone, ${ }^{3}$ Esther S. Choi, ${ }^{1}$ Chris I. De Zeeuw, ${ }^{2}$ \\ Ted L. Petit, ${ }^{3}$ Lucas Pozzo-Miller, ${ }^{4}$ and Alcino J. Silva ${ }^{1}$ \\ ${ }^{1}$ Departments of Neurobiology, Psychiatry, and Psychology, Brain Research Institute, University of California, Los Angeles, California 90095-1761, \\ ${ }^{2}$ Department of Neuroscience, Erasmus Medical Center Rotterdam, 3000 DR Rotterdam, The Netherlands, ${ }^{3}$ Department of Psychology and Program in \\ Neuroscience, University of Toronto, Scarborough, Ontario, Canada M1C 1A4, and ${ }^{4}$ Department of Neurobiology, University of Alabama at Birmingham, \\ Birmingham, Alabama 35294-0021
}

\begin{abstract}
Molecular and cellular studies of the mechanisms underlying mammalian learning and memory have focused almost exclusively on postsynaptic function. We now reveal an experience-dependent presynaptic mechanism that modulates learning and synaptic plasticity in mice. Consistent with a presynaptic function for endogenous H-ras/extracellular signal-regulated kinase (ERK) signaling, we observed that, under normal physiologic conditions in wild-type mice, hippocampus-dependent learning stimulated the ERK-dependent phosphorylation of synapsin I, and MEK (MAP kinase kinase)/ERK inhibition selectively decreased the frequency of miniature EPSCs. By generating transgenic mice expressing a constitutively active form of $\mathrm{H}-\mathrm{ras}\left(\mathrm{H}-\mathrm{ras}^{\mathrm{G}}{ }^{\mathrm{V}}\right)$, which is abundantly localized in axon terminals, we were able to increase the ERK-dependent phosphorylation of synapsin I. This resulted in several presynaptic changes, including a higher density of docked neurotransmitter vesicles in glutamatergic terminals, an increased frequency of miniature EPSCs, and increased paired-pulse facilitation. In addition, we observed facilitated neurotransmitter release selectively during high-frequency activity with consequent increases in long-term potentiation. Moreover, these mice showed dramatic enhancements in hippocampus-dependent learning. Importantly, deletion of synapsin I, an exclusively presynaptic protein, blocked the enhancements of learning, presynaptic plasticity, and long-term potentiation. Together with previous invertebrate studies, these results demonstrate that presynaptic plasticity represents an important evolutionarily conserved mechanism for modulating learning and memory.
\end{abstract}

Key words: Ras; ERK; synapsin; LTP; miniature excitatory postsynaptic currents; mEPSCs; learning; presynaptic

\section{Introduction}

Although extensive evidence supports the involvement of postsynaptic plasticity in mammalian learning and memory (Malenka and Nicoll, 1999; Martin et al., 2000), there is little direct experimental evidence that the complex mechanisms reg-

\footnotetext{
Received July 10, 2005; revised September 1, 2005; accepted September 7, 2005

S.A.K. received support from National Institute of Mental Health-National Research Service Award Grant MH063541, National Institutes of Health (NIH)-National Institute of General Medical Sciences Grant GM08042, the Medical Scientist Training Program, the Aesculapians Fund of the University of California Los Angeles School of Medicine, and the Tennenbaum Family (reativity Initiative. Y.E. was supported by grants from Nederlandse Organisatie voor Wetenschappelijk Onderzoek-Zorgonderzoek Nederland Medische Wetenschappen (VIDI and TOP). This work was also supported by a generous donation from C. M. Spivak and by grants from the Michael Tennenbaum Creativity Initiative, NIH (Grant R01 NS038480), Neurofibromatosis (National, Illinois, Massachusetts Bay Area, Minnesota, Arizona, Kansas and (entral Plains, Mid-Atlantic, and Texas chapters), and the Merck and Neuroscience Nursing Foundations (A.J.S.). We thank L. van Aelst for the human H-ras ${ }^{612 V}$ CDNA, M. Mayford for the pMM403 plasmids, and P. Greengard and J. N. Jovanovic for the phospho-Synl antibodies. We also thank M. Elgersma for help with in situ hybridization and immunohistochemistry. We are grateful to J. G. Borst, D. V. Buonomano, P. W. Frankland, S. A. Josselyn, J. N. Jovanovic, K. C. Martin, T. J. O'Dell, and F. E. Schweizer for fruitful discussions.

*S.A.K. and Y.E. contributed equally to this work.

Correspondence should be addressed to Alcino Silva, Departments of Neurobiology, Psychiatry, and Psychology, Brain Research Institute, University of California, Los Angeles, CA 90095-1761. E-mail: silvaa@mednet.ucla.edu. DOI:10.1523/JNEUROSCI.2836-05.2005

Copyright $\odot 2005$ Society for Neuroscience $\quad 0270-6474 / 05 / 259721-14 \$ 15.00 / 0$
}

ulating presynaptic plasticity also participate in the acquisition and storage of information in mammals (Powell et al., 2004). Studies using a variety of invertebrate systems have provided compelling evidence for the involvement of presynaptic plasticity in invertebrate learning and memory (Burrell and Sahley, 2001). Additionally, computational models have suggested that shortterm presynaptic plasticity is an important mechanism for cortical processing in mammals (Tsodyks and Markram, 1997; Varela et al., 1997; Dobrunz and Stevens, 1999).

By regulating the probability of neurotransmitter release, short-term presynaptic plasticity could affect the induction of long-term changes in synaptic strength thought to underlie learning. In Aplysia, presynaptic neurons require mitogenactivated protein (MAP) kinase/extracellular signal-regulated kinase (ERK) signaling to modulate short- and long-term forms of synaptic plasticity (Martin et al., 1997; Sharma et al., 2003). Furthermore, studies in both Aplysia and mammals have identified a presynaptic mechanism by which ERK-dependent phosphorylation of synapsin I (SynI) modulates neurotransmitter release in neuronal culture (Jovanovic et al., 2000; Humeau et al., 2001; Chin et al., 2002; Chi et al., 2003). 
Synapsin I is localized to presynaptic terminals and tethers synaptic vesicles to the actin cytoskeleton located in the distal reserve pool (Pieribone et al., 1995). Phosphorylation of synapsin I has been shown to regulate its affinity for both actin and synaptic vesicles (Schiebler et al., 1986; Bahler and Greengard, 1987; Benfenati et al., 1989, 1992; Jovanovic et al., 1996). Together, these results suggest a model in which presynaptic ERK signaling acts via synapsin I to modulate neurotransmitter release during the induction of activity-dependent changes in synaptic strength by trafficking synaptic vesicles between the reserve and readilyreleasable pools (Pieribone et al., 1995; Jovanovic et al., 2000, 2001; Chi et al., 2003).

The present study demonstrates that, within the hippocampus, the endogenous $\mathrm{H}$-ras isoform of $\mathrm{p} 21^{\text {Ras }}$, a potent upstream activator of ERK, is abundantly localized to axon terminals. Consistent with a presynaptic function for downstream endogenous $\mathrm{H}$-ras signaling, we observe that, under normal physiologic conditions in wild-type (WT) mice, hippocampus-dependent learning stimulates the phosphorylation of synapsin I, whereas MAP kinase kinase (MEK)/ERK inhibition decreases the frequency of miniature EPSCs (mEPSCs). Furthermore, we took advantage of the subcellular localization of H-ras to manipulate the H-ras/ ERK/synapsin I signaling pathway presynaptically. Our results demonstrate that transgenic expression of active $\mathrm{H}-$ ras $^{\mathrm{G} 12 \mathrm{~V}}$ in mouse glutamatergic forebrain neurons results in an increased frequency of mEPSCs, the facilitation of neurotransmitter release during high-frequency stimulation, consequent increases in long-term potentiation (LTP), and dramatic enhancements in both spatial learning and contextual fear conditioning.

\section{Materials and Methods}

Transgene construction and generation of transgenic mice. The transgene used in these studies is the human $H$-ras cDNA, which carries the G12V mutation. The cDNA is under the control of the $8.5 \mathrm{~kb}$ promoter region of $\alpha$ calcium/calmodulin-dependent kinase II ( $\alpha$ CaMKII) and flanked by $5^{\prime}$ and $3^{\prime}$ artificial splice sites. Using PCR, a sequence encoding the hemagglutinin (HA) epitope was fused $5^{\prime}$ to the $H$-ras ${ }^{G 12 V}$ cDNA (kindly provided by L. van Aelst, Cold Spring Harbor Laboratory, Cold Spring Harbor, NY), as well as a 5' BamHI and 3' FseI restriction sites. This PCR product was cloned in the BamHI-FseI sites of pNN265 (kindly provided by M. Mayford, The Scripps Research Institute, La Jolla, CA), resulting in the addition of a $5^{\prime}$-intron and a $3^{\prime}$-intron plus poly(A) signal from simian virus 40 . The $2100 \mathrm{bp} \mathrm{NotI}$ fragment obtained from this plasmid was cloned in the NotI site downstream of the $\alpha$ CaMKII promoter in the pMM403 vector (kindly provided by M. Mayford). The resulting plasmid (pYE356) was digested with SfiI, and the purified DNA fragment was injected into pronuclei of C57BL/6 zygotes to generate transgenic mice. Transgenic mice were maintained in the background of C57BL/6N (Taconic Farms, Germantown, NY) and crossed with 129/SvEmsJ mice (The Jackson Laboratory, Bar Harbor, ME) to generate F1 animals used for experiments. Synapsin I knock-out mice (Rosahl et al., 1993) were maintained in the background of C57BL/6N (Taconic Farms) and crossed with 129/SvEmsJ mice (The Jackson Laboratory) to generate F1 animals. $\mathrm{H}$-ras ${ }^{G 12 V} /$ synapsin I mice were F2 offspring of F1 $\mathrm{H}$-ras ${ }^{G 12 \mathrm{~V}}$ mice crossed with F1 synapsin I knock-out mice, except $100 \mathrm{~Hz}$ LTP was performed in $\mathrm{H}$-ras ${ }^{G 12 \mathrm{~V}} /$ synapsin I mice of a C57BL/6N genetic background. Consistent with previous reports (Li et al., 1995; Rosahl et al., 1995), synapsin I knock-out mice showing any signs of seizure activity were immediately excluded from experiments. All experiments were performed on adult mice aged 3-6 months old. All experiments were conducted with the experimenter blind to the genotype of the mice and conducted with the approval of the University of California, Los Angeles Animal Research Committee of the Chancellor's Office of Protection of Research Subjects, under continuous supervision of the campus veterinarian.

Expression analysis. In situ hybridization was performed essentially as described by Wisden et al. (1990). The probe used was antisense to the HA sequence: 5' CTC GAC CTA GAA GGT CCT CCC AGG CTG GCA TAG TCA GGC ACG TC 3'. Immunoblot analyses were performed as described previously (Elgersma et al., 2002). In Figures 1 and 4, tissue was collected $30 \mathrm{~min}$ after behavioral training. The primary antibodies used for immunoblot analyses were against pan-Ras (F132, \#32; Santa Cruz Biotechnology, Santa Cruz, CA), phospho-ERK1/2 (New England Biolabs, Beverly, MA), phospho-Akt (New England Biolabs), and synapsin I (Sigma, St. Louis, MO). Phospho-site 3, phospho-site 4/5, and phosphosite 6 antibodies against synapsin I were kindly provided by J. N. Jovanovic (University College, London, UK) and P. Greengard (Rockefeller University, New York, NY). Blots were quantitated using ECL+ and the Storm 860 phosphorimager system (Molecular Dynamics, Sunnyvale, CA).

Immunohistochemistry. Immunohistochemistry was performed using confocal microscopy as described previously (Jaarsma et al., 2001). The primary antibodies used were against $\mathrm{H}$-ras (C20; Santa Cruz Biotechnology), HA-11 (clone 16812; Babco, Richmond, CA), vesicular glutamate transporter 1 (VGLUT1) (Chemicon, Temecula, CA), phosphoERK1/2 (New England Biolabs), phospho-cAMP response elementbinding protein (CREB) (New England Biolabs), and MAP2 [Chemicon (clone AP20; Sigma)]. For triple-labeling confocal immunofluorescence, FITC donkey anti-rabbit, cyanine 3 (Cy3) donkey anti-mouse, and $\mathrm{Cy} 5$ donkey anti-guinea pig from Jackson ImmunoResearch (West Grove, PA) were used as secondary antibodies. Sections were analyzed with a Zeiss (Oberkochen, Germany) LSM 510 confocal laser-scanning microscope using a $63 \times / 1.4$ numerical aperture oil immersion objective.

Immunogold. For EM immunogold immunohistochemistry, $50 \mu \mathrm{m}$ vibratome sections of $4 \%$ paraformaldehyde, $0.1 \%$ glutaraldehyde, transcardially perfused mice were processed for osmium-free embedment (Phend et al., 1995). Ultrathin sections were cut, mounted on Formvarcoated nickel grids, and processed for immunogold labeling using the procedure described by Phend et al. (1995). HA-11 diluted at 1:750 and $10 \mathrm{~nm}$ gold-conjugated goat anti-mouse (Aurion, Wageningen, The Netherlands) diluted 1:30 were used as primary and secondary antibodies, respectively. Gold-labeled sections were analyzed in a Phillips CM10 electron microscope at $80 \mathrm{kV}$.

Golgi analysis. Whole hippocampi from WT and $\mathrm{H}-\mathrm{ras}^{\mathrm{G}}{ }^{12 \mathrm{~V}}$ mice were dissected and processed by a rapid Golgi procedure ( $5 \mathrm{~d}$ in osmium dichromate and $1 \mathrm{~d}$ in silver nitrate), embedded in low-viscosity nitrocellulose, cut at $100-120 \mu \mathrm{m}$ on a sliding microtome, and mounted on glass slides. In each animal, qualitative light microscopic analysis was performed on 10 fully impregnated cells with minimal background artifact. In these cells, dendritic spines were analyzed at $1000 \times$ under oil immersion along random $25 \mu \mathrm{m}$ segments of midapical, apical tuft, and basilar dendrites.

Behavioral analysis. The basic protocol for the water maze experiments has been described previously (Costa et al., 2001). Mice were trained with two trials per day for $9 \mathrm{~d}$ ( $1 \mathrm{~min}$ intertrial interval). Probe trials were administered after 6 and $9 \mathrm{~d}$, as well as $14 \mathrm{~d}$ after the completion of training.

The basic protocol for the contextual fear conditioning experiments has been described previously (Frankland et al., 2001). For experiments using standard delay conditioning, mice were placed in the conditioning chamber for $120 \mathrm{~s}$ before the onset of the unconditioned stimulus (US) (0.4 mA, $1 \mathrm{~s}$ scrambled footshock). Experiments involving three footshocks used a $20 \mathrm{~s}$ intershock interval. For experiments using immediate shock, mice were placed in the conditioning chamber for $2 \mathrm{~s}$ before the onset of the US ( $0.75 \mathrm{~mA}, 2 \mathrm{~s}$ continuous footshock). During the testing phase, conditioning was assessed by measuring freezing and activity for 5 consecutive minutes in the training chamber using a computerized automated scoring system (Anagnostaras et al., 2000). Freezing is operationally defined as a lack of any movement other than that caused by respiration for 2 continuous seconds. Suppression of activity was used as an independent measure of conditioned fear and was calculated as activity $\mathrm{test}_{\text {te }} /\left(\right.$ activity $_{\text {training }}+$ activity $\left._{\text {test }}\right)$. All values are reported as mean \pm SEM. Statistical comparisons were made using ANOVA with Fisher's protected least significant difference (PLSD) for post hoc comparisons.

Electrophysiology. Sagittal hippocampal slices $(400 \mu \mathrm{m})$ were placed in 
a submerged recording chamber and perfused continuously at a rate of $1.5 \mathrm{ml} / \mathrm{min}$ with artificial CSF (ACSF) equilibrated with $95 \% \mathrm{O}_{2}, 5 \% \mathrm{CO}_{2}$ at $30^{\circ} \mathrm{C}$. ACSF contained the following (in $\mathrm{mM}$ ): $120 \mathrm{NaCl}, 3.5 \mathrm{KCl}, 2.5$ $\mathrm{CaCl}_{2}, 1.3 \mathrm{MgSO}_{4}, 1.25 \mathrm{NaH}_{2} \mathrm{PO}_{4}, 26 \mathrm{NaHCO}_{3}$, and 10 D-glucose. Extracellular recording of field EPSP (fEPSPs) were made in CA1 stratum radiatum with platinum/iridium electrodes (Frederick Haer Companu, Bowdoinham, ME). In all experiments, one bipolar platinum/iridium electrode was used to stimulate Schaffer collateral/commissural afferents orthodromically. During LTP studies, a second electrode was used to monitor an independent control pathway. Experiments to observe responses during theta-burst stimulation (TBS) and 5 and $10 \mathrm{~Hz}$ stimulation were performed in the presence of $50 \mu \mathrm{M}$ D-2-amino-5phosphonopentanoate (APV) and $100 \mu \mathrm{m}$ picrotoxin with CA3 removed to prevent epileptic discharges. Paired-pulse facilitation (PPF) experiments were conducted in the presence of $50 \mu \mathrm{M}$ APV. All stimulus pulses were $100 \mu \mathrm{s}$ in duration and one-third to two-thirds of the maximum fEPSP. Average stimulation strength and baseline fEPSP was similar between genotypes for all of the experiments conducted. For LTP studies, short-term potentiation (STP) was defined as the first posttetanic measurement, made $30 \mathrm{~s}$ after LTP induction.

Whole-cell current-clamp recordings were used to study the induction of LTP by low-frequency presynaptic fiber stimulation paired with postsynaptic depolarization. In these experiments, slices with the CA3 region removed were bathed in normal ACSF containing $100 \mu \mathrm{M}$ picrotoxin. EPSPs evoked by $0.05 \mathrm{~Hz}$ presynaptic fiber stimulation were recorded from CA1 pyramidal neurons using an Axoclamp 2B amplifier (Axon Instruments, Union City, CA) in bridge mode. Patch electrodes had resistances of 5-7 M $\Omega$ and contained a $\mathrm{K}^{+}$-based solution (in $\mathrm{mM}$ ): 120 potassium methyl-sulfate, $20 \mathrm{KCl}, 0.2$ EGTA, HEPES, $2 \mathrm{MgCl}_{2}, 4$ $\mathrm{Na}_{2}$-ATP, 0.3 Tris-GTP, and 7 phosphocreatine. LTP was induced by pairing each of 100 presynaptic fiber stimuli delivered at $0.5 \mathrm{~Hz}$, with a $200 \mathrm{~ms}, 0.8 \mathrm{nA}$ square-pulse current injection through the whole-cell patch electrode beginning $+5 \mathrm{~ms}$ after presynaptic fiber stimulation.

Whole-cell voltage-clamp recordings using a 3900A Integrating Patch Clamp Amplifier (Dagan, Minneapolis, MN) were performed to measure spontaneous mEPSCs. In this experiment, we used ACSF (in mM): $126 \mathrm{NaCl}, 2.5 \mathrm{KCl}, 2 \mathrm{CaCl}_{2}, 2 \mathrm{MgCl}_{2}, 1.25 \mathrm{NaH}_{2} \mathrm{PO}_{4}, 26 \mathrm{NaHCO}_{3}, 10$ D-glucose, 0.001 TTX, 0.025 CGP-35348 [3-amino-propyl(diethoxymethyl)phosphinic acid], 0.05 picrotoxin, and $0.05 \mathrm{APV}$. The recording protocol involved a baseline mEPSC recording in ACSF, changing to bath perfusion with ACSF containing U0126 [1,4-diamino2,3-dicyano-1,4-bis (o-aminophenylmercapto) butadiene] $(10 \mu \mathrm{m})$ for $15 \mathrm{~min}$, followed by another mEPSC recording. Intracellular pipette solution contained the following (in $\mathrm{mm}$ ): $135 \mathrm{CsCl}, 4 \mathrm{NaCl}, 2 \mathrm{MgCl}_{2}, 10$ HEPES, 0.05 EGTA, 5 QX-314 [ $N$-(2,6-dimethylphenyl carboylmethyl) triethylammonium bromide], $2 \mathrm{Mg}$-ATP, and $0.5 \mathrm{Na}_{2}$-GTP. Voltageclamp recordings were made at a holding potential of $-70 \mathrm{mV}$. The direct current resistances of the electrodes were 4-6 $\mathrm{M} \Omega$. Series resistance was compensated by $70-90 \%$ using lag values of $7-10 \mu \mathrm{s}$. Before compensation, series resistance was $<15 \mathrm{M} \Omega$. All recordings were acquired and low-pass filtered (eight-pole Bessel; Brownlee Precision 200, Brownlee Precision, Santa Clara, CA) at $10 \mathrm{kHz}$ and digitized on-line at $20 \mathrm{kHz}$ using a PCI-MIO-IGE data acquisition board (National Instruments, Austin, TX).

Average LTP was assessed during the final $10 \mathrm{~min}$ of each protocol. Statistical comparisons were made using the number of mice as the sample size. ANOVA was used with Fisher's PLSD for post hoc comparisons. The Kolmogorov-Smirnov test was used to compare cumulative probability distributions of LTP. All values are reported as mean \pm SEM. Statistical comparisons of mEPSC data were performed using paired and unpaired $t$ tests. mEPSC data were analyzed using custom-written software. Synaptic plasticity data were acquired and analyzed using pClamp 7.0 (Axon Instruments).

Analysis of presynaptic vesicle distribution. Electron microscopy using random sampling of synapses was performed as described previously (Pozzo-Miller et al., 1999). Only complete profiles of nonperforated asymmetric synapses on dendritic spines in stratum radiatum of area CA1 were photographed. The parameters measured in each synapse were length of the active zone, thickness of the postsynaptic density (PSD), total number of small $(\sim 50 \mathrm{~nm})$ synaptic vesicles per terminal, and number of docked vesicles. The docked vesicles are defined as those up to one-vesicle-diameter $(\sim 50 \mathrm{~nm})$ distance from the active zone, according to criteria developed by Dickinson-Nelson and Reese (1983), because these vesicles have been shown to be depleted during sustained, repetitive activity.

Electron microscopy using three-dimensional terminal reconstruction was performed as described previously (Schikorski and Stevens, 1997, 2001). Briefly, for each animal, a series of electron micrographs were obtained at a final magnification of $30,000 \times$ from a ribbon of $28-36$ serial sections in stratum radiatum of area CA1. Only complete terminals containing a single nonperforated asymmetric synapse on a dendritic spine were analyzed. The parameters measured in each terminal were total terminal volume, area of the PSD, total number of synaptic vesicles per terminal, and number of docked vesicles. The docked vesicles are defined as those in which no visible gap existed between the vesicle and the membrane wall opposite the PSD (Schikorski and Stevens, 1997).

\section{Results}

\section{Enhanced phosphorylation of synapsin I during learning}

Although previous studies have demonstrated a robust increase in ERK activation after experience-dependent plasticity (English and Sweatt, 1996; Atkins et al., 1998), few downstream effectors have been identified that contribute to learning and synaptic plasticity (Adams et al., 2000; Yuan et al., 2002). Synapsin I has been identified previously as a prominent downstream effector of ERK (Jovanovic et al., 1996), but phosphorylation-dependent regulation has never been evaluated during learning. Using contextual fear conditioning, we evaluated the dynamics of ERKdependent synapsin I phosphorylation. During contextual fear conditioning, an association is formed between a distinct context and an aversive footshock delivered in that context. However, significantly decreasing the interval between placement into the conditioning context and delivery of the footshock limits hippocampus-dependent processing of the context. Administering the footshock immediately after introducing animals to the training context (immediate shock) prevents the formation of the contextual representation necessary for fear conditioning (Fanselow, 1990; Rudy et al., 2002). Consistent with a robust and specific function in presynaptic signaling during learning, wildtype C57BL/6N mice showed increased ERK-dependent synapsin I phosphorylation during contextual conditioning compared with the immediate shock condition (Fig. $1 A, B)\left(F_{(1,6)}=10.18\right.$; $p<0.05)$. Phosphorylation of ERK2 was also increased with a similar specificity (Fig. $1 A, B)\left(F_{(1,6)}=8.29 ; p<0.05\right)$.

\section{H-ras localizes to axon terminals and signals through ERK}

We sought to explore the function of ERK-dependent synapsin I phosphorylation in learning and synaptic plasticity by engineering transgenic mice to express $\mathrm{HA}$-tagged $\mathrm{H}$-ras containing a substitution of glycine- 12 for valine $\left(\mathrm{H}-\right.$ ras $\left.^{\mathrm{G} 12 \mathrm{~V}}\right)$ under the control of the $\alpha$ CaMKII promoter (Mayford et al., 1995). The $\mathrm{H}$-ras ${ }^{\mathrm{G} 12 \mathrm{~V}}$ transgene is a potent upstream activator of ERK in postmitotic neurons (Rosen et al., 1994; Heumann et al., 2000; Koh et al., 2002). In addition, the late postnatal onset of the $\alpha C a M K I I$ promoter restricts transgene expression to postmitotic neurons, thereby minimizing putative developmental effects caused by the oncogenic properties of the transgene.

The transgenic allele $\left(H-\right.$ ras $\left.^{G 12 V}\right)$ was inherited in the expected Mendelian frequency, and $H$-ras ${ }^{G 12 V}$ mice appeared healthy with no gross behavioral or anatomical abnormalities. Nissl-stained brain sections appeared normal with no gross morphological changes (Fig. 2A). To study the expression pattern of the transgene, in situ hybridization was performed on coronal sections 


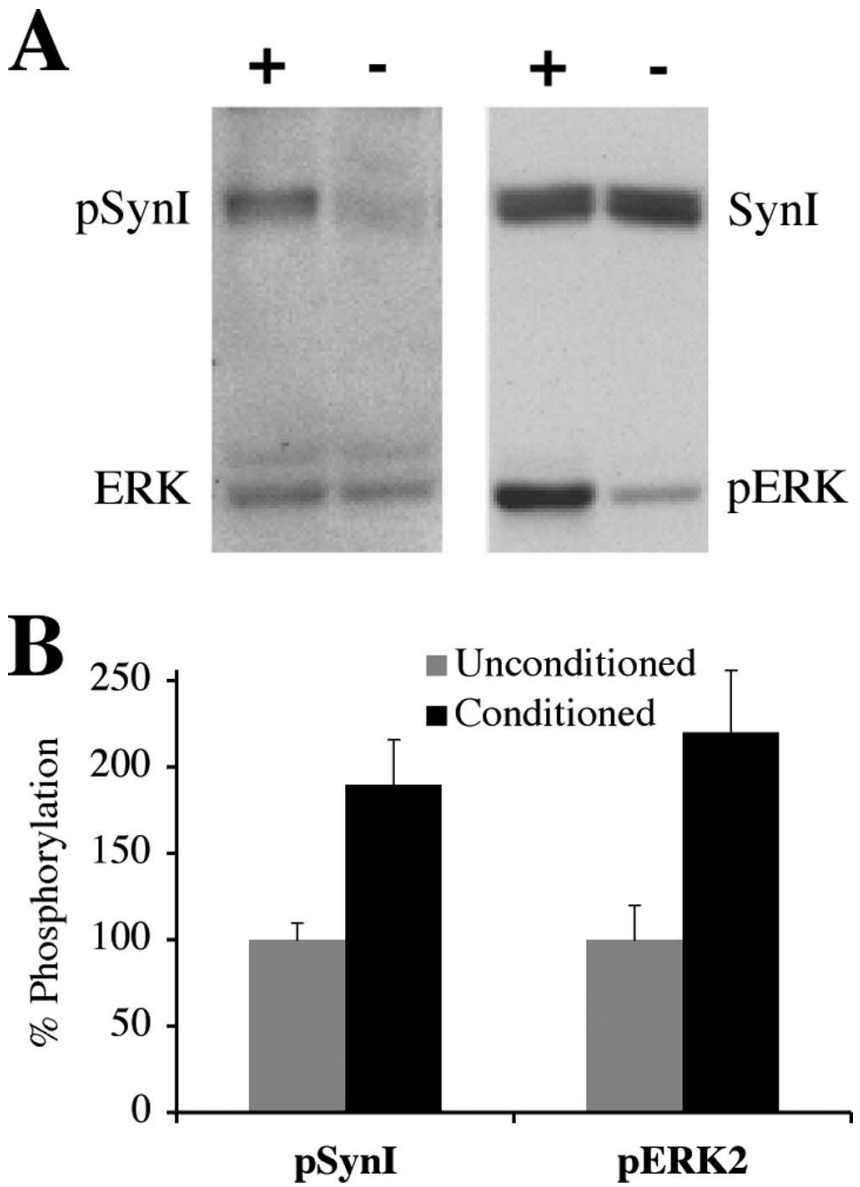

Figure 1. ERK and synapsin I sites $4 / 5$ are phosphorylated in C57BL/6N mice during contextual conditioning. $A$, Immunoblot of hippocampal lysates using a phospho-synapsin I antibody against sites $4 / 5$ (pSynl), phospho-ERK1/2 antibody (pERK), and antibodies against total synapsin I (Synl) and total ERK1/2 (ERK). The second blot was obtained after stripping the first blot and reprobing with the antibodies indicated. + symbols denote normal contextual conditioning with a 3 min delay before the footshock was given. - symbols denote that the shock was delivered immediately after placement in the chamber. $\boldsymbol{B}$, Quantification of synapsin I phosphorylation at sites $4 / 5$ and ERK2 phosphorylation shows a significant increase in conditioned mice $[+, n=3]$ compared with the mice that received a shock immediately after placement in the chamber $[-, n=3]$.

from adult $H$-ras ${ }^{G 12 V}$ and WT mice using a probe specific for the transgene. mRNA expression was evident throughout the forebrain, including cortex, striatum, and amygdala, with particularly high concentration in the hippocampus, in which staining was restricted to the pyramidal cell layer in CA regions and to the granule cell layer in the dentate gyrus (Fig. $2 B$ ).

Previous studies have suggested that fourfold to fivefold overexpression of $\mathrm{H}$-ras ${ }^{\mathrm{G} 12 \mathrm{~V}}$ results in significant cytoarchitectural changes in pyramidal neurons (Gartner et al., 2004). However, in our mice, we observed a normal dendritic spine density, quantified by stereologic analysis of Golgi-stained pyramidal neurons in CA1 stratum radiatum (WT, $1.55 \pm 0.05$ spines $/ \mu \mathrm{m}^{3} ; \mathrm{H}$-ras ${ }^{\mathrm{G} 12 \mathrm{~V}}$, $1.58 \pm 0.06$ spines $\left./ \mu \mathrm{m}^{3} ; F_{(1,223)}=0.04 ; p=0.84\right)$. The absence of morphological changes in the H-ras ${ }^{G 12 V}$ mice likely reflects the moderate level of transgene overexpression compared with endogenous $\mathrm{H}$-ras (Fig. 2C) (110 $\pm 16 \%$ of endogenous H-ras). No significant change in endogenous $\mathrm{H}$-ras expression was observed in $\mathrm{H}$-ras ${ }^{G 12 \mathrm{~V}}$ mice compared with WT littermates (Fig. $2 C)(p=0.44)$.

Although previous studies have implicated $\mathrm{p} 21^{\text {Ras }}$ in neuronal function, isoform-specific subcellular localization in neurons has
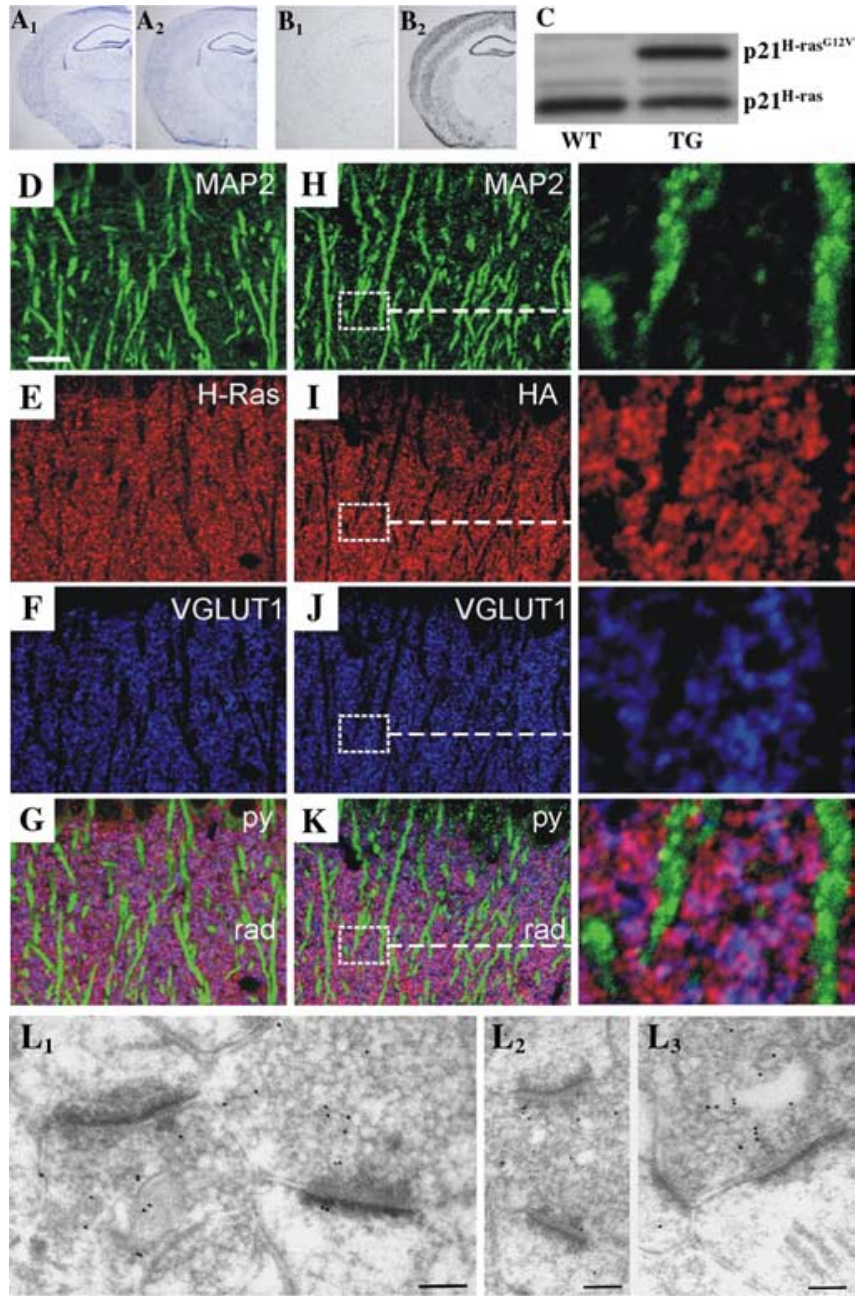

Figure 2. H-ras is predominantly localized to axon terminals in the hippocampus of adult animals. $A$, WT $\left(A_{1}\right)$ and $H$-ras ${ }^{G 12 V}\left(A_{2}\right)$, Nissl staining demonstrated normal gross anatomical morphology. $\boldsymbol{B}$, In situ hybridization of adult coronal sections showed no detectable $\mathrm{H}_{\text {-ras }}{ }^{G 12 \mathrm{~V}}$ expression in WT slices $\left(\boldsymbol{B}_{1}\right)$, whereas in transgenic mice, strong expression was evident throughout the cerebral cortex and hippocampus with less staining in the striatum and amygdala $\left(\boldsymbol{B}_{2}\right)$. C, Immunoblot of hippocampal lysates obtained from WT and transgenic $\mathrm{H}$-ras ${ }^{612 \mathrm{~V}}$ mice (TG) using an $\mathrm{H}$-ras antibody. Expression of transgenic $\mathrm{HA}$-tagged $\mathrm{H}$-ras ${ }^{\mathrm{G}}{ }^{\mathrm{VV}}$ (top band in TG lane) is comparable with endogenous $\mathrm{H}$-ras (bottom bands). $\boldsymbol{D}-\boldsymbol{K}$, Confocal microscopy images of the hippocampus obtained after triple labeling with $\alpha$-MAP2 (D, $\boldsymbol{H}$; green), $\alpha$-H-ras (E) or $\alpha$-HA $(\boldsymbol{I})($ red), and $\alpha$-VGLUT1 $(\boldsymbol{F}, \boldsymbol{J}$; blue). $\boldsymbol{D}-\boldsymbol{G}$ were obtained from adult WT mice, and $\boldsymbol{H}-\boldsymbol{K}$ were obtained from adult transgenic mice. Overlay images $(\boldsymbol{G}, \boldsymbol{K})$ demonstrate that, in WT mice $(\mathbf{G})$, endogenous $\mathrm{H}$-ras is excluded from the MAP2 compartment but shows extensive colocalization (purple) with the excitatory presynaptic marker VGLUT1. In transgenic mice $(\boldsymbol{K})$, $\mathrm{H}$ ras $^{\mathrm{G}}{ }^{\mathrm{GV}}$ shows a similar subcellular distribution as endogenous $\mathrm{H}$-ras. py, CA1 pyramidal cell layer; rad, stratum radium. Scale bar (in D), $4 \mu \mathrm{m}$. L, Immunogold electron microscopy demonstrates that $\mathrm{H}-\mathrm{ras}^{\mathrm{G}}{ }^{\mathrm{V} V} \mathrm{~V}$ is located predominantly in axon terminals in stratum radiatum of the CA1 region with significantly less labeling in postsynaptic spines. Note that the postsynaptic profile in $L_{3}$ contains a spine apparatus. Scale bars: $L_{1} 170 \mathrm{~nm} ; L_{2}, 130 \mathrm{~nm} ; L_{3}, 190 \mathrm{~nm}$.

not been well characterized. Therefore, we examined the subcellular localization of endogenous $\mathrm{H}$-ras and transgenic $\mathrm{H}$-ras ${ }^{\mathrm{G} 12 \mathrm{~V}}$. Confocal microscopy in the hippocampal CA1 region of WT mice demonstrated extensive colocalization between endogenous H-ras and the excitatory presynaptic marker VGLUT1. In contrast, there was no significant overlap between $\mathrm{H}$-ras and the dendritic marker MAP2 (Fig. 2D-G). In transgenic mice, the subcellular distribution of $\mathrm{H}$-ras ${ }^{\mathrm{G} 12 \mathrm{~V}}$ was similar to endogenous $\mathrm{H}$-ras and highly localized with the presynaptic marker VGLUT1 (Fig. $2 \mathrm{H}-\mathrm{K}$ ). Analogous to endogenous $\mathrm{H}$-ras, the distribution of 
transgenic $\mathrm{H}$-ras ${ }^{\mathrm{G} 12 \mathrm{~V}}$ showed little overlap with MAP2 (Fig. $2 G, K)$, consistent with a predominantly axonal localization of H-ras.

Because confocal immunofluorescence microscopy does not provide adequate resolution to independently evaluate expression in presynaptic axon terminals and postsynaptic dendritic spines, we performed immunogold analysis using electron microscopy to examine the synaptic distribution of $\mathrm{H}-$ ras $^{\mathrm{G} 12 \mathrm{~V}}$. Gold particles were highly abundant in presynaptic axon terminals (Fig. $2 L_{1}-L_{3}$ ). In contrast, substantially less labeling was present in postsynaptic dendritic spines. The ratio of the number of gold particles in presynaptic terminals to that in postsynaptic spines was $3.5 \pm 0.19$ (paired $\left.t_{(41)}=9.8 ; p<0.001\right)$.

Importantly, although we observed a predominantly presynaptic localization of H-ras in the hippocampus of mature animals, we observed abundant $\mathrm{H}$-ras ${ }^{\mathrm{G} 12 \mathrm{~V}}$ localization at presynaptic as well as postsynaptic sites in primary hippocampal cultures (Y. Elgersma and D. Jaarsma, unpublished data), consistent with previous reports (Zhu et al., 2002), suggesting that the localization of $21^{\text {Ras }}$ isoforms in vivo may be developmentally regulated.

We next sought to examine the effects of $\mathrm{H}$-ras ${ }^{\mathrm{G} 12 \mathrm{~V}}$ expression on downstream signaling pathways. Consistent with many previous studies demonstrating p $21^{\text {Ras }}$-mediated activation of neuronal ERK (Rosen et al., 1994; Heumann et al., 2000; Iida et al., 2001; Adams and Sweatt, 2002; Koh et al., 2002; Komiyama et al., 2002), H-ras ${ }^{\mathrm{G} 12 \mathrm{~V}}$ mice had increased levels of phosphorylated ERK1 and ERK2 without a change in total ERK1/2 expression (Fig. $3 A, B)$ (pERK1, $F_{(1,9)}=24.9, p<0.001$; pERK2, $F_{(1,9)}=$ $10.2, p<0.01$; total ERK1, $F_{(1,9)}=0.26, p=0.62$; total ERK2, $\left.F_{(1,9)}=0.16, p=0.74\right)$. In contrast, phosphorylated and total levels of Akt, a downstream effector of phosphoinositide-3 kinase, were both unchanged (Fig. $3 A, B)$ (pAkt, $F_{(1,9)}=0.002, p=$ 0.96 ; total Akt, $\left.F_{(1,9)}=0.97, p=0.35\right)$. These results are consistent with a biochemical specificity of downstream H-ras effector activation observed in previous studies using neuronal $\mathrm{H}-$ ras $^{\mathrm{G} 12 \mathrm{~V}}$ in vivo (Heumann et al., 2000; Koh et al., 2002). Immunohistochemical analysis in the hippocampal CA1 region demonstrated that areas containing increased pERK $1 / 2$ corresponded closely to those expressing $\mathrm{H}$-ras ${ }^{\mathrm{G} 12 \mathrm{~V}}$ (Fig. $3 C-F$ ). In contrast, no change in the number of pERK1/2- or pCREB-positive $(+)$ nuclei were observed (Fig. $3 E-H$ ), consistent with the absence of $\mathrm{H}$-ras ${ }^{\mathrm{G} 12 \mathrm{~V}}$ in the pyramidal cell-body layer (Fig. 3D). Therefore, these data suggest that $\mathrm{H}$-ras expression is highly abundant in axon terminals and functions to regulate local ERK activation.

\section{Synapsin I phosphorylation is increased in $\mathrm{H}-$ ras $^{G 12 V}$ mice}

We next sought to characterize ERK activation and ERKdependent phosphorylation of synapsin I in $\mathrm{H}$-ras ${ }^{G 12 V}$ mice. Hippocampal lysates were prepared from H-ras ${ }^{\mathrm{G} 12 \mathrm{~V}}$ and WT littermates after contextual fear conditioning with either an immediate shock or delayed shock. There was a significant interaction of genotype with conditioning on ERK activation and on phosphorylation of synapsin I at the ERK-dependent sites $4 / 5$ (Fig. $4 A, B)\left(\right.$ pERK2, $F_{(1,9)}=4.56, p=0.077$; pSynI, $F_{(1,9)}=4.75$, $p=0.072$ ). Consistent with the experiment in Figure 1 conducted with mice from a C57BL/6N genetic background, contextual conditioning in WT mice $(\mathrm{C} 57 \mathrm{BL} / 6 \mathrm{~N} \times 129 \mathrm{SvEmsJ} \mathrm{F} 1$ hybrid) significantly increased phosphorylation of both synapsin I and ERK2 (Fisher's PLSD; pSynI, $p<0.05$; pERK2, $p<0.05$ ). In contrast, synapsin I and ERK2 phosphorylation were equivalent between $\mathrm{H}$-ras ${ }^{G 12 \mathrm{~V}}$ mice receiving contextual conditioning and immediate shock and were similar to conditioned WT mice (pSynI, $p=0.94$; pERK2, $p=0.75$ ). Importantly, phosphoryla-

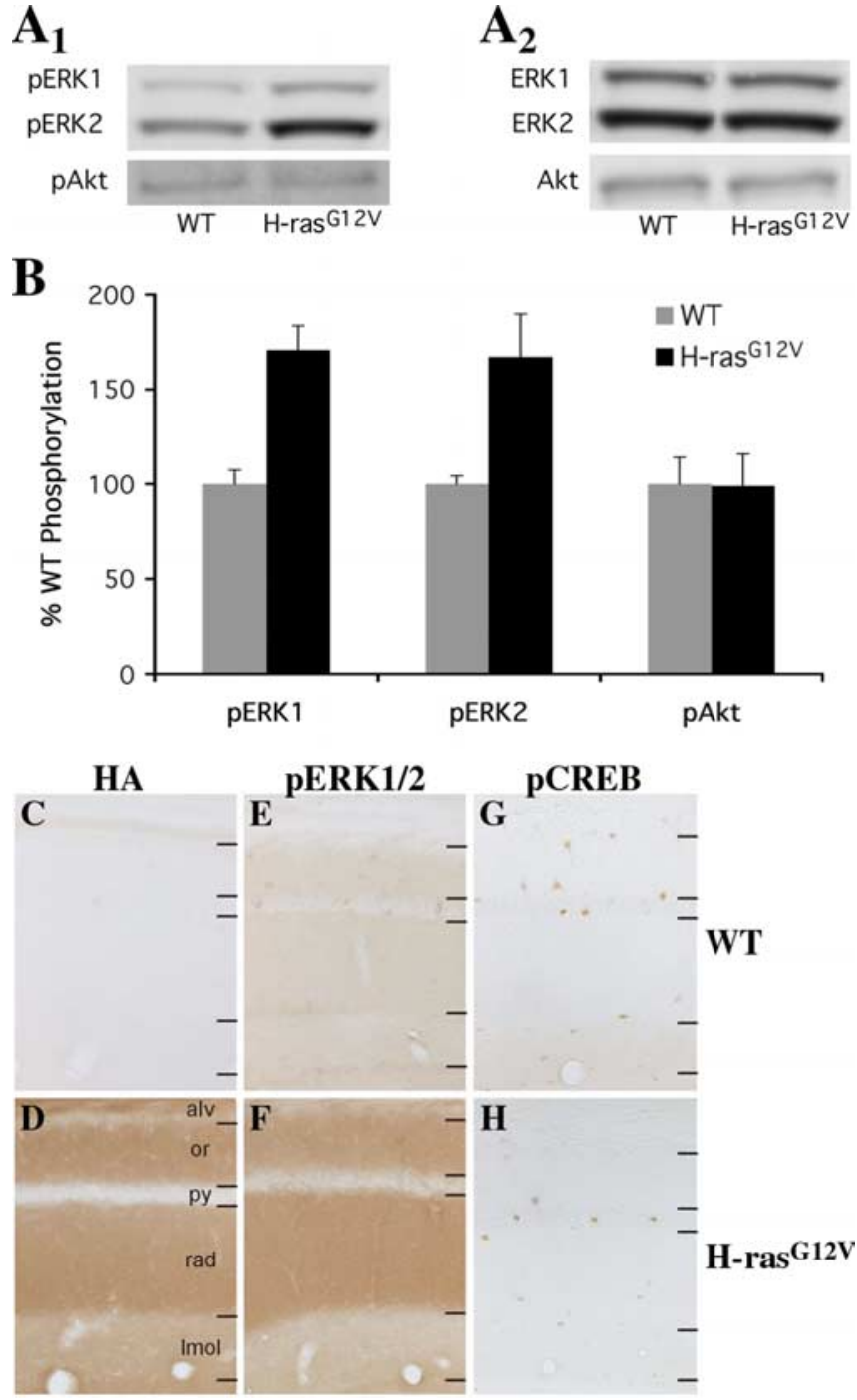

Figure 3. Increased ERK signaling in $H$-ras ${ }^{G 12 V}$ mice. $\boldsymbol{A}$, Immunoblots of phosphorylated $\left(\boldsymbol{A}_{\boldsymbol{1}}\right)$ and total $\left(A_{2}\right)$ forms of the downstream H-ras effectors ERK1, ERK2, and Akt from hippocampal lysates. Blots shown in $A_{2}$ were obtained after stripping the blots shown in $A_{1}, B$, Quantification of changes in the phosphorylation of downstream $\mathrm{H}$-ras effectors demonstrated a significant increase of pERK1 and pERK2 in $\mathrm{H}$-ras ${ }^{G 12 V}$ mice without any observable changes in pAkt (WT, $\left.n=6 ; H_{-r a s}{ }^{G 12 V}, n=5\right)$. $(-H$, Within the CA1 hippocampal region, areas of increased pERK1/2 $(\boldsymbol{E}, \boldsymbol{F})$ correspond closely with $\mathrm{H}$-ras ${ }^{\mathrm{G} 12 \mathrm{~V}}$ expression $(\boldsymbol{C}, \boldsymbol{D})$. Note that the nuclear localization of both pERK1/2 and pCREB was normal in $H$-ras ${ }^{G 12 V}$ mice $(\boldsymbol{F}, \boldsymbol{H})$ compared with control mice $(\boldsymbol{E}$, $G)$, consistent with the absence of transgene expression in the somatodendritic compartment. alv, Alveolus; or, stratum oriens; py, pyramidal cell layer; rad, stratum radiatum; Imol, stratum lacunosum moleculare.

tion of synapsin I and ERK2 after hippocampus-dependent learning was equivalent between WT and $\mathrm{H}$-ras ${ }^{G 12 V}$ mice, arguing that the transgenic manipulation produces biochemical changes that are observed physiologically during learning in WT mice (pSynI, $p=0.84$; pERK2, $p=0.43$ ).

In contrast to the differences observed at the ERK-dependent sites 4/5, synapsin I phosphorylation at the CaMKII-dependent site 3 (Bahler and Greengard, 1987) was equivalent in WT and $H$-ras ${ }^{G 12 V}$ mice (WT, $100 \pm 11.7 \% ; H$-ras ${ }^{G 12 V}, 89.5 \pm 10.3 \%$; $\left.F_{(1,9)}=0.44 ; p=0.52\right)$, demonstrating the specificity of the transgenic manipulation. Together, these data suggest that learningrelated presynaptic biochemical changes in H-ras/ERK/synapsin I signaling are potentiated in $\mathrm{H}$-ras ${ }^{\mathrm{G} 12 \mathrm{~V}}$ mice. 

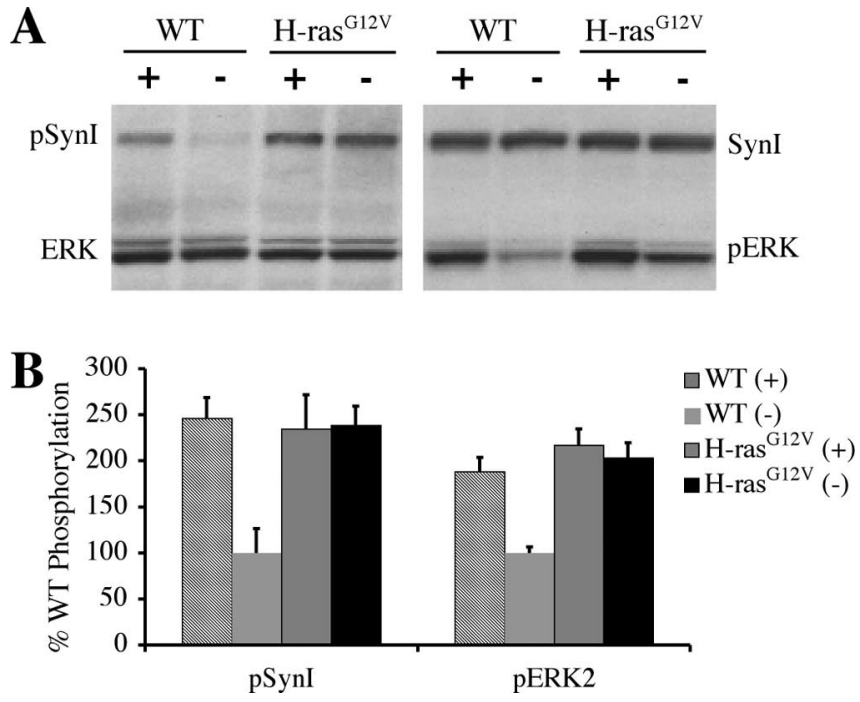

Figure 4. Phosphorylation of ERK and synapsin I sites $4 / 5 \mathrm{in} \mathrm{H}$-ras ${ }^{G 12 V}$ mice receiving unconditioned shock is comparable with pERK and pSynl levels in conditioned WT mice. A, Immunoblot of hippocampal lysates obtained from conditioned and immediately shocked WT and $H$-ras ${ }^{612 V}$ mice using phospho-synapsin I antibodies against sites 4/5, pERK antibodies, and antibodies against total synapsin I and ERK. The second blot was obtained after stripping the first blot and reprobing with the antibodies indicated. + symbols denote normal contextual conditioning with a 3 min delay before the footshock was delivered. - symbols denote that the shock was given immediately after placement in the chamber. B, Quantification of ERK2 phosphorylation and synapsin I phosphorylation at sites $4 / 5$ shows a significant increase in WT conditioned mice that received a delayed shock compared with WT mice that received a shock immediately after placement in the chamber. Note that pERK and pSynl levels of immediately shocked $\mathrm{H}$-ras $^{G 12 \mathrm{~V}}$ mice are comparable with the levels observed in WT conditioned (delay shocked) animals ( $n=3$, for each condition).

\section{Enhanced presynaptic plasticity in $\mathrm{H}-\mathrm{ras}^{G 12 \mathrm{~V}}$ mice}

Together, the predominantly presynaptic localization of H-ras and enhanced phosphorylation of synapsin I suggest that presynaptic function may be altered in $\mathrm{H}-\mathrm{ras}^{\mathrm{G}}{ }^{2 \mathrm{~V}}$ mice. To explore the frequency-dependent impact of the $\mathrm{H}$-ras ${ }^{G 12 \mathrm{~V}}$ mutation on short-term plasticity, we examined PPF, which is thought to depend primarily on presynaptic mechanisms (Dobrunz et al., 1997; Zucker and Regehr, 2002). Indeed, $\mathrm{H}$-ras ${ }^{G 12 V}$ mice showed a frequency-dependent enhancement of PPF (Fig. 5A) $\left(F_{(8,88)}=\right.$ 3.4; $p<0.01)$, performed in the presence of APV to block postsynaptic plasticity. At interpulse intervals $\leq 100 \mathrm{~ms}$, PPF was significantly larger in $\mathrm{H}$-ras ${ }^{G 12 \mathrm{~V}}$ mice than WT littermates (PLSD, $p<0.001$ ). However, at longer intervals, PPF was equivalent in $H$-ras ${ }^{G 12 V}$ and WT mice (PLSD, $p>0.42$ ). Together, these data suggest a model in which synaptic transmission is enhanced in $\mathrm{H}$-ras ${ }^{G 12 \mathrm{~V}}$ mice during high-frequency stimulation although low-frequency responses are normal. Consistent with this model, baseline synaptic transmission was normal in $\mathrm{H}$-ras ${ }^{G 12 \mathrm{~V}}$ mice (Fig. $5 B-D)\left(F_{(4,76)}=0.07 ; p=0.99\right)$.

During high-frequency stimulation of the hippocampal Schaffer collateral pathway, depletion of presynaptic neurotransmitter vesicles from the readily-releasable pool occurs rapidly. This is a key mechanism regulating the rate of shortterm synaptic depression and serves to limit postsynaptic depolarization (Dobrunz and Stevens, 1997; Brager et al., 2002). To probe the trafficking of reserve pool vesicles to the readilyreleasable pool after depletion, we measured responses during a prolonged $10 \mathrm{~Hz}$ tetanus in the presence of APV and picrotoxin, which has been used in previous studies to examine vesicle trafficking (Rosahl et al., 1995; Dobrunz and Stevens, 1997; Schnell and Nicoll, 2001; Chi et al., 2003). Responses to stimulation at this frequency reveal the competing processes of facilitation, depression, vesicle depletion, and vesicle mobilization (Dobrunz and Stevens, 1997). H-ras ${ }^{G 12 V}$ mice showed significantly larger responses at the end of the tetanus, suggesting an increased rate for mobilization of reserve pool vesicles into the readily-releasable pool (Fig. $5 E)\left(F_{(1,12)}=5.2\right.$; $p<0.05)$. These data further support a model in which ERKdependent synapsin I phosphorylation enhances neurotransmitter release selectively during patterns of stimulation that significantly deplete the readily-releasable pool of presynaptic neurotransmitter vesicles.

\section{Presynaptic plasticity enhancement requires synapsin I}

The data presented above suggest that increased trafficking of synaptic vesicles to the readily-releasable pool by ERKphosphorylated synapsin I may underlie the increased responses to high-frequency stimulation in $\mathrm{H}$-ras ${ }^{G 12 \mathrm{~V}}$ mice. To examine whether synapsin $\mathrm{I}$ is required for mediating the effects of the $H$-ras ${ }^{G 12 V}$ transgene, we crossed synapsin I knock-out mice (Rosahl et al., 1993) with the H-ras ${ }^{G 12 V}$ transgenics. Next, we examined whether synapsin I mediates the presynaptic facilitation of release during high-frequency stimulation in $\mathrm{H}$-ras ${ }^{G 12 V}$ mice. Indeed, there was a significant interaction of genotype on fEPSP responses during the $10 \mathrm{~Hz}$ tetanus measured in the presence of APV and picrotoxin (Fig. $5 F)\left(F_{(3,24)}=4.8 ; p<0.01\right)$. As expected in mice carrying the wild-type synapsin $I$ allele, $H$-ras ${ }^{G 12 V}(+)$ mice showed significantly larger responses during the tetanus than $H$-ras ${ }^{G 12 V}$-negative (-) littermates (Fig. 5F) (PLSD, $p<0.05)$. However, in the background of the synapsin I knock-out allele, $\mathrm{H}$-ras ${ }^{G 12 V}(+)$ and $H$-ras ${ }^{G 12 V}(-)$ mice showed equivalent responses throughout the tetanus (Fig. 5F) (PLSD, $p=0.90)$. These results strongly argue that synapsin I is necessary to mediate the enhanced presynaptic plasticity observed in $H$-ras ${ }^{G 12 V}$ mice.

\section{Increased density of docked vesicles in $\mathrm{H}-$ ras $^{G 12 V}$ mice}

Synapsin I plays a critical role in establishing the distribution of synaptic vesicles within axon terminals (Hilfiker et al., 1999; Humeau et al., 2001). The finding of a synapsin I-mediated increase in neurotransmitter release during high-frequency stimulation led us to hypothesize that $H$-ras ${ }^{G 12 V}$ mice may have an altered distribution of vesicles in presynaptic terminals. Using electron microscopy, we directly addressed this possibility by quantifying the number of morphologically docked vesicles at presynaptic active zones of Schaffer collateral-CA1 synapses, the anatomical correlate of the readily-releasable pool (Dickinson-Nelson and Reese, 1983; Pozzo-Miller et al., 1999; Schikorski and Stevens, 2001) (Fig. 6A). Indeed, significantly more docked vesicles were observed in synapses from $H$-ras ${ }^{G 12 V}$ mice (Fig. $\left.6 B\right)\left(F_{(1,118)}=\right.$ $29.5 ; p<0.001)$. Additional measurements of the total number of vesicles, active zone area, axon terminal volume, postsynaptic density thickness, and synapse density were normal in $\mathrm{H}$-ras ${ }^{\text {G12 V }}$ mice (data not shown).

In an independent group of mice, we also performed threedimensional reconstruction of synaptic terminals using unbiased serial sectioning (Schikorski and Stevens, 1997, 2001). Again, we found a significant increase in docked vesicle density in $\mathrm{H}$-ras ${ }^{G 12 \mathrm{~V}}$ terminals (Fig. 6C) $\left(F_{(1,58)}=12.6 ; p<0.001\right)$. Together, these data provide anatomical evidence that $\mathrm{H}$-ras/ERK-dependent phosphorylation of synapsin I regulates the size of the readilyreleasable pool of neurotransmitter vesicles. 

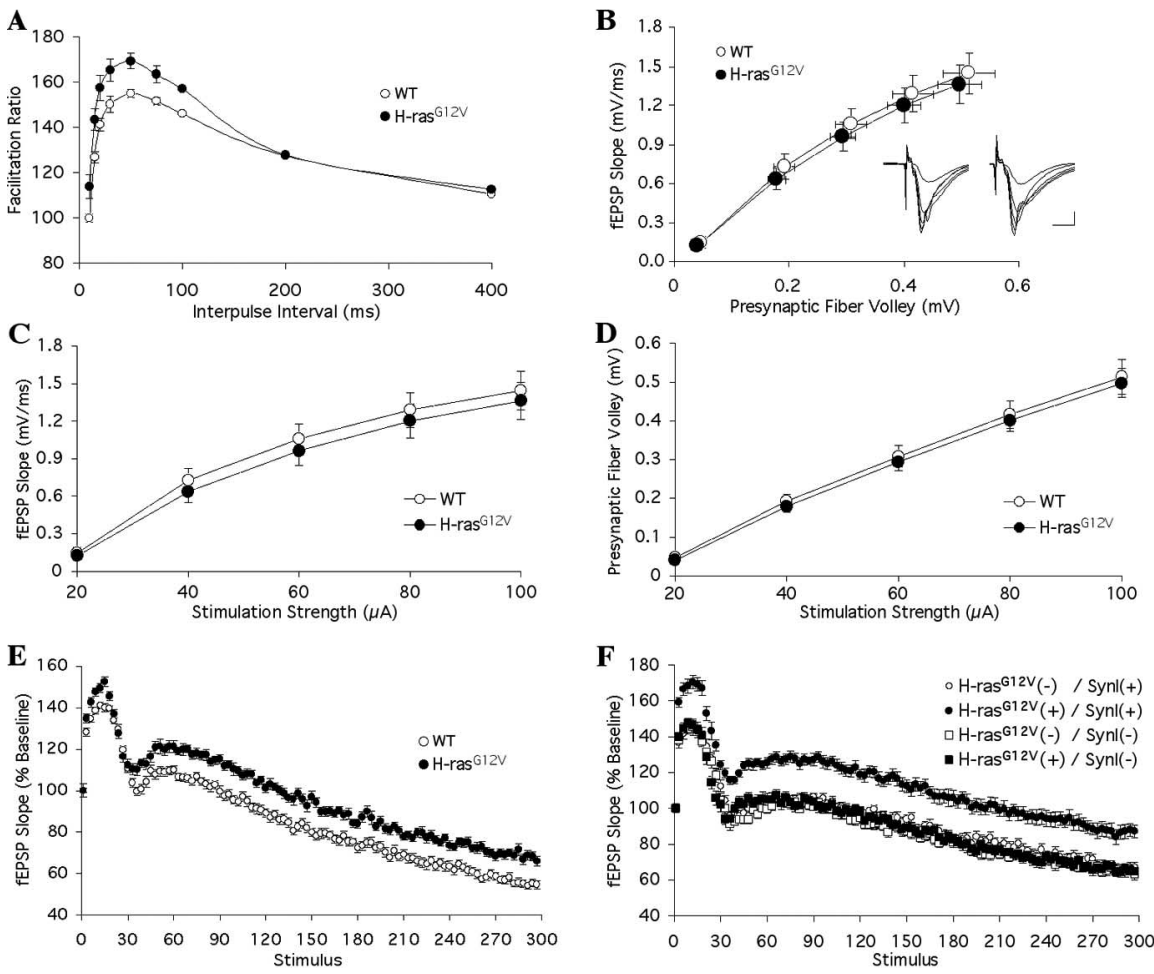

Figure 5. Presynaptic changes in $\boldsymbol{H}$-ras ${ }^{G 12 V}$ mice are mediated by synapsin I. $\boldsymbol{A}$, Paired-pulse facilitation was enhanced in H-ras $^{612 V}$ mice for intervals $\leq 100$ ms but normal for longer intervals (WT, 9 slices, 7 mice; $H$-ras ${ }^{612 V}$, 8 slices, 6 mice). B-D, Basal synaptic transmission was normal in WT (10 slices, 10 mice) and $H$-ras ${ }^{G 12 V}$ (11 slices, 11 mice) littermates. Plots show the fEPSP as a function of the evoked presynaptic fiber volley $(\boldsymbol{B})$, the fEPSP as a function of stimulation strength $(\boldsymbol{C})$, and the presynaptic fiber volley as a function of stimulation strength (D). Inset in $\boldsymbol{B}$ shows representative traces (left, WT; right, $H$-ras ${ }^{G 12 V}$ ). Calibration: 5 ms, $0.5 \mathrm{mV}$. $\boldsymbol{E}$, Reserve pool mobilization during high-frequency stimulation in WT and $\mathrm{H}$-ras ${ }^{G 12 V}$ mice was probed by $10 \mathrm{~Hz}$ ( $30 \mathrm{~s}$ ) tetanization in the presence of APV and picrotoxin. Compared with WT littermates ( 9 slices, 7 mice), H-ras ${ }^{612 V}$ mice (9 slices, 7 mice) showed larger responses throughout the tetanus. $\boldsymbol{F}$, Reserve pool mobilization during high-frequency stimulation in WT and $\mathrm{H}$-ras ${ }^{G 12 \mathrm{~V}}$ mice with or without the presence of the synapsin / gene. The mobilization was probed using $10 \mathrm{~Hz}(30 \mathrm{~s})$ tetanization in the presence of APV and picrotoxin. $H-\operatorname{ras}^{G 12 V}(+) / S y n I(+)$ mice (7 slices, 7 mice) showed significantly larger fEPSPs than H-ras $^{G 12 V}(-) / S y n I(+)$ (7 slices, 7 mice) throughout the tetanus. In contrast, deletion of synapsin / prevented the increased plasticity because $\mathrm{H}$-ras ${ }^{G 12 V}(-) / S y n /(-)\left(7\right.$ slices, 7 mice) and $\mathrm{H}$-ras ${ }^{G 12 V}(+) / S y n I(-)(7$ slices, 7 mice) showed equivalent responses.

ERK activity modulates mEPSC frequency but not amplitude Our electrophysiologic data suggest that, during patterns of activity that tend to rapidly deplete the readily-releasable pool of neurotransmitter vesicles, $H$-ras ${ }^{G 12 V}$ mice have an attenuation of homosynaptic depression. The demonstration of an increased size of the morphologically docked pool of vesicles further supports our model of presynaptic H-ras/ERK signaling in which ERK-dependent phosphorylation of synapsin I shifts the distribution of presynaptic vesicles toward the readily-releasable pool. Therefore, we measured spontaneous mEPSCs in CA1 pyramidal neurons to further examine the functional effects of the alteration in synaptic vesicle distribution in $\mathrm{H}$-ras ${ }^{G 12 V}$ mice (Fig. 6D-H). Consistent with a presynaptic locus for the observed alterations in synaptic plasticity of $\mathrm{H}$-ras ${ }^{G 12 \mathrm{~V}}$ mice, mEPSC frequency was significantly increased without any change in mEPSC amplitude (unpaired $t$ test; frequency, $t_{(1,24)}=9.19, p<0.001$; amplitude, $\left.t_{(1,24)}=0.43, p=0.67\right)$.

We have hypothesized that ERK-dependent phosphorylation of synapsin I is an important biochemical event that modulates presynaptic plasticity. Our results have demonstrated that robust physiologic ERK-dependent synapsin I phosphorylation occurs during learning in WT mice. We also hypothesized that, through increased downstream ERK activity, transgenic expression of
$\mathrm{H}$-ras ${ }^{\mathrm{G} 12 \mathrm{~V}}$ requires synapsin I to mediate an enhancement of presynaptic plasticity. Therefore, we perfused the MEK inhibitor U0126 into the extracellular solution immediately after the baseline mEPSC recordings to ask two important questions. First, does presynaptic MEK/ERK activity modulate neurotransmitter release under normal physiologic conditions in WT mice? Second, is the increased mEPSC frequency observed in $\mathrm{H}$-ras ${ }^{G 12 V}$ mice dependent on a high level of downstream MEK/ ERK activity?

After introduction of U0126 into the extracellular solution, the frequency of mEPSCs decreased significantly in CA1 pyramidal neurons of WT mice without any observed change in mEPSC amplitude (paired $t$ test; frequency, $t_{(1,24)}=7.15, p<$ 0.001 ; amplitude, $\left.t_{(1,24)}=0.58, p=0.57\right)$, demonstrating that, under normal physiologic conditions, ERK activity modulates presynaptic neurotransmitter release. Additionally, U0126 completely abolished the increase in mEPSC frequency observed in $\mathrm{H}$-ras ${ }^{G 12 \mathrm{~V}}$ mice without affecting mEPSC amplitude (unpaired $t$ test; frequency, $t_{(1,24)}=0.16, p=0.88$; amplitude, $\left.t_{(1,24)}=0.28, p=0.78\right)$, confirming that the ERK pathway downstream of $\mathrm{H}$-ras is responsible for the changes in presynaptic function in $\mathrm{H}$-ras ${ }^{G 12 \mathrm{~V}}$ mice. These data further support our model hypothesizing that presynaptic neurotransmitter release is modulated over a short temporal window by presynaptic H-ras/ERK/synapsin I signaling.

\section{Frequency-dependent enhancement of presynaptic plasticity and LTP}

Because $H$-ras ${ }^{G 12 V}$ mice show anatomical and functional changes at presynaptic sites, we next investigated whether the observed alterations in presynaptic plasticity were relevant during the induction of LTP in $H$-ras ${ }^{G 12 V}$ mice. To explore this possibility, we examined LTP at the Schaffer collateral-CA1 synapse in acute hippocampal slices. We focused on the Schaffer collateral pathway because many previous studies have demonstrated that LTP at this synapse is crucial for learning contextual and spatial information (Martin et al., 2000). LTP was first induced using five TBS, which mimics the in vivo activity of hippocampal neurons during exploratory behavior (Larson et al., 1986; Otto et al., 1991). TBS consisted of four stimuli delivered at $100 \mathrm{~Hz}$ with a $200 \mathrm{~ms}$ interval between bursts. Significantly more LTP and STP were observed after five TBS in $H$-ras ${ }^{G 12 V}$ mice (Fig. 7A) (LTP, $F_{(1,12)}=4.8, p<0.05$; STP, $\left.F_{(1,12)}=11.2, p<0.01\right)$. In addition, the cumulative probability distribution of LTP was shifted toward significantly larger potentiation after five TBS (Fig. 7B) (Kolmogorov-Smirnov test, $D=0.71 ; p=0.056$ ). Therefore, $\mathrm{H}$-ras ${ }^{\mathrm{G} 12 \mathrm{~V}}$ expression enhanced the induction of both short- and long-term changes in synaptic strength after high-frequency presynaptic stimulation.

The predominantly presynaptic localization of $\mathrm{H}-\mathrm{ras}^{\mathrm{G} 12 \mathrm{~V}}$ as well as the larger STP suggests that the enhancement in LTP could 
be mediated by increased neurotransmitter release during high-frequency stimulation. To evaluate this possibility, we recorded fEPSPs during five TBS in the presence of APV and picrotoxin to block NMDA receptor-dependent postsynaptic plasticity and GABA-mediated inhibition, respectively. A significant increase in fEPSP amplitude was observed in response to each theta burst in $\mathrm{H}$-ras ${ }^{G 12 V}$ mice (Fig. $7 C)\left(F_{(19,266)}=23.5, p<0.001\right)$. In contrast, fEPSPs returned to normal between the bursts $\left(F_{(4,56)}=1.0 ; p=0.40\right)$, suggesting that the enhancement in STP may be frequency dependent.

We next sought to examine the interaction between the observed changes in short-term plasticity and long-term potentiation in $\mathrm{H}$-ras ${ }^{G 12 \mathrm{~V}}$ mice. If the enhanced LTP after TBS in $H$-ras ${ }^{G 12 V}$ mice is mediated by increased presynaptic release during induction, then LTP should be normal when induced using lower frequencies of presynaptic stimulation that do not result in substantial homosynaptic depression. Indeed, $5 \mathrm{~Hz}$ LTP was indistinguishable between WT and $\mathrm{H}$-ras ${ }^{\mathrm{G} 12 \mathrm{~V}}$ mice (Fig. $7 D)\left(F_{(1,10)}=0.002 ; p=0.97\right)$, and the cumulative probability distribution was normal (Fig. $7 E)(D=0.25 ; p=$ 0.96). Similarly, $H$-ras ${ }^{G 12 V}$ mice showed normal fEPSPs throughout the equivalent $5 \mathrm{~Hz}$ stimulus delivered in the presence of $\mathrm{APV}$ and picrotoxin (Fig. $7 F)\left(F_{(1,12)}=\right.$ $0.002 ; p=0.97)$. Therefore, our results suggest that the alterations in long-term synaptic plasticity observed in the transgenic mice are a direct consequence of the frequency-dependent modulation of presynaptic neurotransmitter release during LTP induction.

Our model predicts that STP and LTP are enhanced in $\mathrm{H}$-ras ${ }^{G 12 \mathrm{~V}}$ mice selectively after high-frequency stimulation protocols known to substantially deplete the readily-releasable pool. Therefore, similar to the STP and LTP enhancements observed with TBS, a different highfrequency induction protocol should also produce increased potentiation in $H$-ras ${ }^{G 12 V}$ mice. Indeed, both STP and LTP induced using a $100 \mathrm{~Hz}$ tetanus resulted in significantly more potentiation in $H$-ras ${ }^{G 12 V}$ mice (Fig. 8A) (LTP, $F_{(1,28)}=$ $10.1, p<0.01$; STP, $F_{(1,28)}=23.0, p<$ $0.001)$. Additionally, the cumulative probability distribution was shifted toward significantly larger LTP in $\mathrm{H}$-ras ${ }^{G 12 \mathrm{~V}}$ mice (Fig. $8 B)(D=0.53 ; p<0.05)$. These data suggest that both short- and long-term synaptic potentiation are enhanced in $H$-ras ${ }^{G 12 V}$ mice selectively after high-frequency stimulation, consistent with a frequency-dependent increase in presynaptic release.

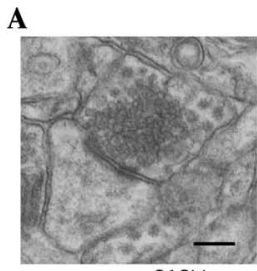

H-ras ${ }^{\mathrm{G} 12 \mathrm{~V}}$
D

E 0.6

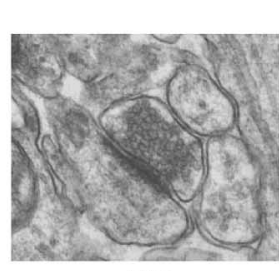

WT
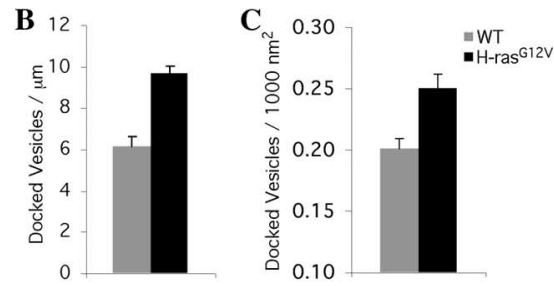

Baseline

U0126
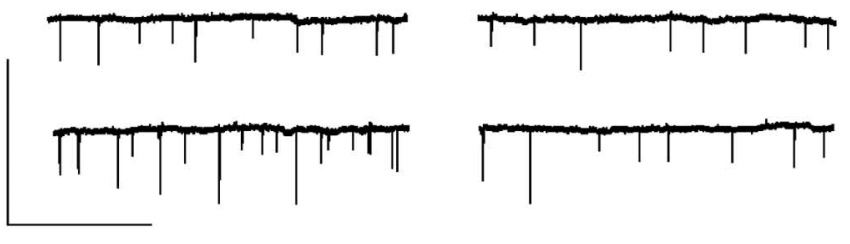

WT

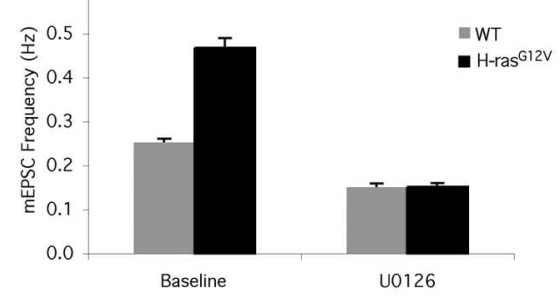

$\mathbf{F}_{20}$
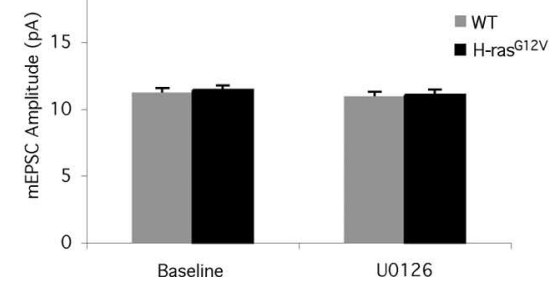

Figure 6. $\quad H-r a s^{G 12 V}$ mice have more docked vesicles at presynaptic active zones. $\boldsymbol{A}$, Representative electron micrographs of excitatory synapses onto dendritic spines in CA1 stratum radiatum. Scale bar, $200 \mathrm{~nm}$. $\boldsymbol{B}$, Using random sampling of excitatory synapses, $H$-ras ${ }^{G 12 V}$ mice had significantly more docked vesicles at presynaptic active zones (WT, 62 synapses, 3 mice; $H$-ras ${ }^{G 12 V}$, 58 synapses, 3 mice). C, Three-dimensional reconstruction of synaptic terminals confirmed the increased density of docked vesicles (WT, 30 synapses, 3 mice; $H_{\text {-ras }}{ }^{G 12 V}$, 30 synapses, 3 mice). D, Representative traces of mEPSC recordings in WT and $H$-ras ${ }^{G 12 V}$ mice at baseline and after application of the MEK inhibitor U0126. Calibration: $10 \mathrm{~s}, 40$ pA. $\boldsymbol{E}$, mEPSC frequency was significantly increased in $\mathrm{H}$-ras ${ }^{G 12 V}$ neurons and rescued by the application of U0126. Note that WT neurons showed a significant reduction in $\mathrm{mEPSC}$ frequency during application of U0126, consistent with a functional presynaptic H-ras/ERK pathway under normal physiologic conditions. $\boldsymbol{F}$, mEPSC amplitude was maintained in $\mathrm{H}$-ras ${ }^{G 12 V}$ neurons and unaltered by application of U0126.
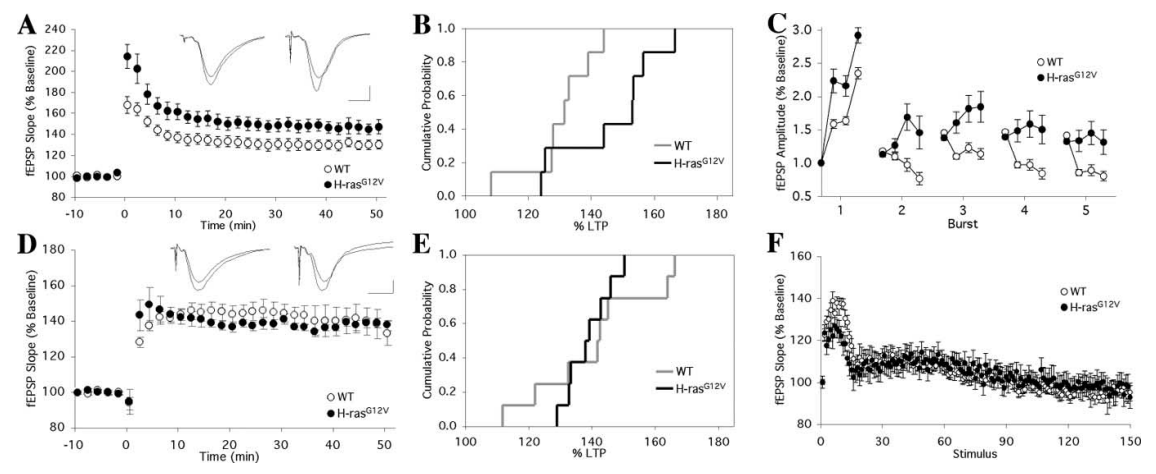

Figure 7. High-frequency stimulation augments neurotransmitter release and enhances long-term potentiation in $H$-ras ${ }^{G 12 \mathrm{~V}}$ mice. $\boldsymbol{A}$, LTP induced by a five TBS protocol was increased in $\mathrm{H}$-ras ${ }^{G 12 \mathrm{~V}}$ mice. Short-term potentiation measured $30 \mathrm{~s}$ after the tetanus was also increased (WT, 7 slices, 7 mice; $H_{-r a s}{ }^{G 12 V}, 7$ slices, 7 mice). $B$, Cumulative probability distribution of LTP for the five theta-burst protocol shows significantly larger LTP in $H$-ras ${ }^{G 12 V}$ mice. C, fEPSP amplitude was significantly increased during TBS delivered in the presence of APV and picrotoxin (WT, 8 slices, 8 mice; $H$-ras ${ }^{G 12 V}$, 8 slices, 8 mice). D, Low-frequency LTP induced using $5 \mathrm{~Hz}\left(30 \mathrm{~s}\right.$ ) stimulation was normal between WT (8 slices, 6 mice) and $\mathrm{H}$-ras $^{612 \mathrm{~V}}$ ( 8 slices, 6 mice) littermates. $\boldsymbol{E}$, Cumulative probability distribution of $5 \mathrm{~Hz}$ LTP shows normal probability distributions between WT and $H$-ras ${ }^{G 12 V}$ mice. $\boldsymbol{F}$, Responses during $5 \mathrm{~Hz}\left(3 \mathrm{~s}\right.$ s) stimulation in the presence of APV and picrotoxin were also equivalent (WT, 7 slices, 7 mice; $\mathrm{H}_{\text {-ras }}{ }^{612 \mathrm{~V}}, 7$ slices, 7 mice). Representative traces $(\boldsymbol{A}, \boldsymbol{D})$ are shown at baseline and during LTP (left, WT; right, H-ras ${ }^{G 12 V}$ ). Calibration: $5 \mathrm{~ms}, 0.5 \mathrm{mV}$.

$H$-ras ${ }^{G 12 V}$ mice show normal pairing-induced associative LTP Our model for the presynaptic frequency-dependent effects of $\mathrm{H}$-ras ${ }^{\mathrm{G} 12 \mathrm{~V}}$ also predicts that NMDA-dependent associative LTP induced by low-frequency presynaptic stimulation, which does not significantly challenge the readily-releasable pool, should be 
A
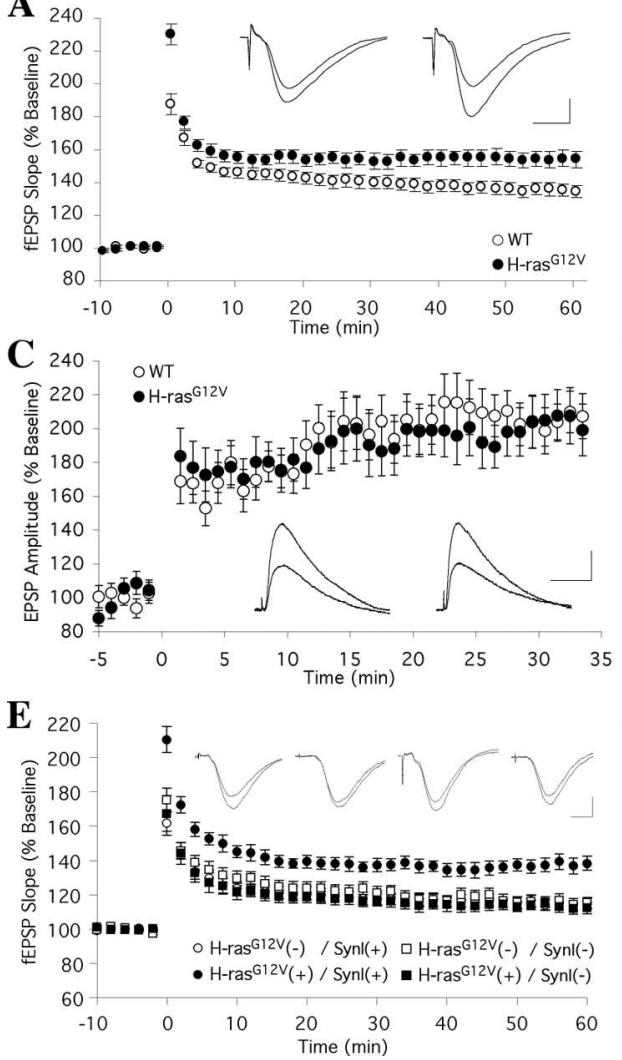

B

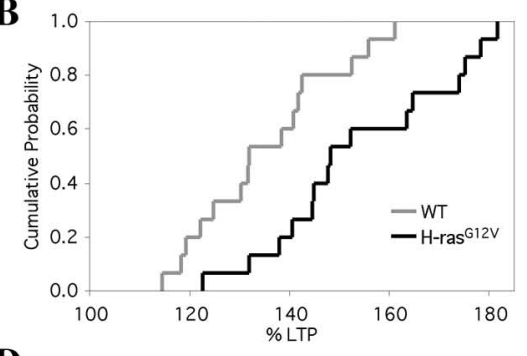

D

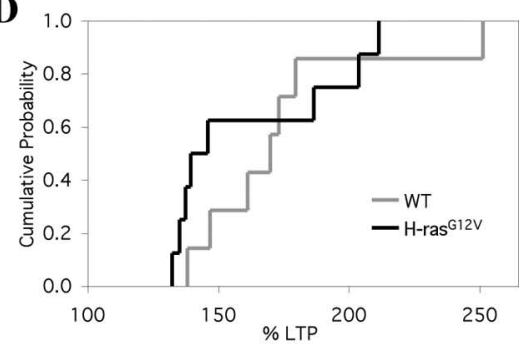

$\mathbf{F}$

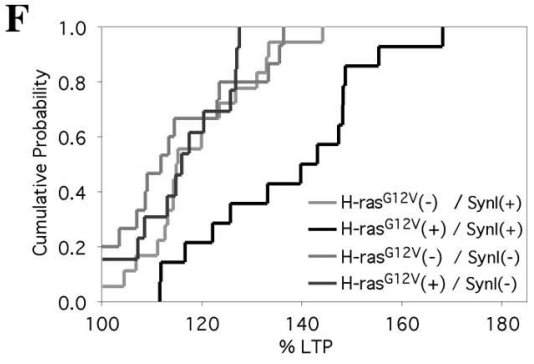

Figure 8. LTP enhancement in $H$-ras ${ }^{G 12 V}$ mice is mediated by a presynaptic mechanism during induction. A, Both STP and LTP induced by $100 \mathrm{~Hz}(1 \mathrm{~s})$ tetanization were increased in $\mathrm{H}$-ras ${ }^{612 \mathrm{~V}}$ mice (WT, 15 slices, 15 mice; $\mathrm{H}$-ras $^{G 12 \mathrm{~V}}$, 15 slices, 15 mice). Representative traces are shown at baseline and during LTP (left, WT; right, $H$-ras ${ }^{612 V}$ ). Calibration: $5 \mathrm{~ms}, 0.5 \mathrm{mV}$. B, Cumulative probability distribution of $100 \mathrm{~Hz}$ LTP shows significantly larger LTP in $\mathrm{H}$-ras ${ }^{612 \mathrm{~V}}$ mice. C, Pairing LTP induced under whole-cell patch clamp at $0.5 \mathrm{~Hz}(50 \mathrm{~s})$ using single presynaptic stimuli and $200 \mathrm{~ms}$ of $0.8 \mathrm{nA}$ postsynaptic depolarization. WT ( 9 cells, 7 mice) and $H$-ras ${ }^{G 12 V}$ (10 cells, 8 mice) showed equivalent LTP. Representative traces are shown at baseline and during LTP (left, WT right, $\mathrm{H}$-ras ${ }^{G 12 V}$ ). Calibration: $30 \mathrm{~ms}, 3 \mathrm{mV}$. D, Cumulative probability distribution of LTP induced with $0.5 \mathrm{~Hz}$ pairing is equivalent between WT and $\mathrm{H}$-ras ${ }^{G 12 V}$ mice. $\boldsymbol{E}$, Both STP and LTP induced by $100 \mathrm{~Hz}(1 \mathrm{~s})$ tetanization were increased in $\mathrm{H}$-ras ${ }^{612 V}(+)$ mice with a wild-type synapsin / allele $\left[H\right.$-ras ${ }^{G 12 V}(+) / S y n l(+), 19$ slices, 9 mice; -ras $^{G 12 V}(-) / S y n l(+), 14$ slices, 7 mice]. However, the plasticity enhancements were abolished in the absence of synapsin I $\left[H-\right.$ ras $^{612 V}(+) / S y n l(-), 15$ slices, 5 mice; $H_{-r a s}{ }^{G 12 V}(-) /$ Synl(-), 14 slices, 5 mice]. Representative traces are shown at baseline and during LTP [left to right, $H-$ ras $^{G 12 V}(+) / S y n l(+)$, $H_{-r a s^{612 V}}(-) / S y n l(+), H-$ ras $^{G 12 V}(+) / S y n l(-), H-$ ras $\left.^{G 12 V}(-) / S y n l(-)\right]$. Calibration: $5 \mathrm{~ms}, 0.2 \mathrm{mV}$. F, Cumulative probability distribution of $100 \mathrm{~Hz}$ LTP shows that the LTP enhancement in $\mathrm{H}$-ras ${ }^{612 V}$ mice requires the presynaptic protein synapsin I.

normal in $\mathrm{H}$-ras ${ }^{G 12 V}$ mice. Using whole-cell patch clamp, LTP was reliably induced by 100 pairings at $0.5 \mathrm{~Hz}$ of a single presynaptic stimulus with a $200 \mathrm{~ms}$ postsynaptic current injection and train of action potentials (APs). The whole-cell patch-clamp configuration provided an additional opportunity to detect changes in postsynaptic plasticity because many previous studies have demonstrated that associative LTP requires intact postsynaptic ERK signaling (Watanabe et al., 2002; Zhu et al., 2002; Selcher et al., 2003). Therefore, we used potassium methyl-sulfate in the patch pipette solution to avoid blockade of A-type potassium channels that are modulated by postsynaptic ERK and regulate dendritic excitability (Yuan et al., 2002; Frick et al., 2004). Consistent with intact postsynaptic function in $\mathrm{H}-\mathrm{ras}^{\mathrm{Gl}}{ }^{12 \mathrm{~V}}$ mice, LTP was normal (Fig. $8 C, D)\left(F_{(1,13)}=0.49, p=0.49\right.$; cumulative probability distribution, $D=0.48, p=0.35$ ). Importantly, AP frequency, AP amplitude, AP threshold, membrane potential, and input resistance were also unchanged in $\mathrm{H}-\mathrm{ras}^{\mathrm{G}}{ }^{2 \mathrm{~V}}$ mice (data not shown). Together, these data strongly suggest that enhanced LTP in $\mathrm{H}-\mathrm{ras}^{G 12 \mathrm{~V}}$ mice results from increased synaptic transmission during high-frequency stimulation. Conversely, because low-frequency stimulation does not significantly challenge the presynaptic readily-releasable pool, LTP induced under these conditions is normal. These results highlight the specificity of the electrophysiologic changes and suggest that presynaptic plasticity is enhanced in $H$-ras ${ }^{G 12 V}$ mice although postsynaptic function is normal.

\section{Enhanced long-term potentiation requires synapsin I}

Consistent with a frequency-dependent facilitation of presynaptic neurotransmitter release, $\mathrm{H}-\mathrm{ras}^{G 12 \mathrm{~V}}$ mice demonstrate an enhancement in LTP using induction protocols with high-frequency, but not lowfrequency, presynaptic stimulation. Thus far, we have demonstrated that a critical downstream effector of $\mathrm{H}$-ras/ERK in modulating short-term presynaptic plasticity is synapsin I. To further examine our hypothesis that synapsin I is a necessary downstream target of presynaptic H-ras/ ERK signaling for the modulation of synaptic plasticity, we performed $100 \mathrm{~Hz}$ LTP in mice carrying the $\mathrm{H}$-ras ${ }^{G 12 V}$ transgene in a C57BL/6 genetic background with a targeted deletion of synapsin I (Fig. 8E,F). There was a significant effect of genotype on the magnitude of LTP induced (Fig. $8 E)\left(F_{(3,59)}=9.10 ; p<0.001\right)$. Consistent with our previous experiments using highfrequency LTP induction protocols, in mice carrying the wild-type synapsin $I$ allele, $H-\operatorname{ras}^{G 12 V}(+)$ mice showed significantly larger LTP (Fig. 8E) (PLSD, $p<$ 0.001 ), with a significant shift in the cumulative probability distribution (Fig. $8 F$ ) $(D=0.64 ; p<0.01)$. However, in the background of the synapsin I knock-out allele, $H-r^{G a s}{ }^{G 12 V}(+)$ and $H-r a s^{G 12 V}(-)$ mice showed an equivalent magnitude of LTP (Fig. $8 E)(p=0.83)$ and similar cumulative probability distributions (Fig. $8 F)(D=0.22 ; p=0.85$ ). Importantly, in the absence of the $H$-ras ${ }^{G 12 V}$ transgene, we replicated the previously published finding that synapsin I knock-out mice have normal $100 \mathrm{~Hz}$ LTP (Rosahl et al., 1993) [Fig. $8 E$ ( $p=$ $0.33), F(D=0.31 ; p=0.41)]$. Therefore, the presynaptic H-ras/ ERK signaling pathway requires synapsin I as a necessary downstream target for modulation of presynaptic plasticity and LTP.

\section{Enhanced hippocampus-dependent learning}

To examine the effects of increased $\mathrm{H}$-ras/ERK/synapsin I signaling on spatial learning, we trained $\mathrm{H}$-ras ${ }^{G 12 V}$ mice and WT littermates using the Morris water maze. In this hippocampusdependent task, mice learn to navigate to a submerged platform by using extra-maze cues (Morris et al., 1982). H-ras ${ }^{G 12 V}$ and WT mice showed equivalent latencies to find the hidden platform during training, with no differences in swimming speed or floating (data not shown). Spatial learning was assessed using probe trials (Brandeis et al., 1989) in which the platform was removed from the pool and the search path was recorded. $\mathrm{H}-\mathrm{ras}^{G 12 \mathrm{~V}}$ mice spent significantly more time in the target quadrant than WT mice during the probe trial conducted on day 6 (Fig. 9A) 
$\left(F_{(1,23)}=4.7 ; p<0.05\right)$. Additionally, the cumulative probability distribution of target quadrant occupancy times revealed that, compared with their WT littermates, $H$-ras ${ }^{G 12 V}$ mice showed higher selectivity in their probe trial search path (Fig. 9B). The learning enhancement was confirmed using two additional measures to assess spatial learning during the probe trial. First, H-ras ${ }^{G 12 V}$ mice searched significantly closer to the target platform location than WT mice $\left(H\right.$-ras ${ }^{G 12 V}, 45.1 \pm 3.3$ $\mathrm{cm}$; WT, $56.3 \pm 3.2 \mathrm{~cm} ; F_{(1,23)}=6.0 ; p<$ $0.05)$. Second, the number of crossings through the target platform location was significantly higher in $\mathrm{H}-\mathrm{ras}^{\mathrm{G}}{ }^{2} \mathrm{~V}(3.0 \pm 0.7$ crosses) than WT mice ( $1.2 \pm 0.4$ crosses $)$ $\left(F_{(1,23)}=4.7 ; p<0.05\right)$.

After 3 additional days of training, WT mice improved the selectivity of their probe trial search to a similar level as $H$-ras ${ }^{G 12 V}$ littermates (Fig. 9C) $\left(F_{(1,23)}=\right.$ $0.40 ; p=0.53)$. These results indicate that, although $\mathrm{H}$-ras ${ }^{G 12 \mathrm{~V}}$ mice require less training to learn the spatial location of the target platform, additional training allows WT mice to improve their search strategy to a similar asymptotic level.

Although $\mathrm{H}$-ras ${ }^{G 12 \mathrm{~V}}$ mice demonstrate enhanced spatial learning, an important question is the stability of their memory for the target platform location. Therefore, we tested mice in a probe trial conducted $14 \mathrm{~d}$ after the end of training. Importantly, both groups maintained an equivalently high level of target quadrant selectivity (WT, $40.9 \pm 6.3 \%$ time; $H$-ras ${ }^{G 12 V}, 49.3 \pm$ $4.5 \%$ time; $\left.F_{(1,23)}=1.2 ; p=0.28\right)$, confirming that the long-term stability of spatial memory in $\mathrm{H}$-ras ${ }^{G 12 V}$ mice is intact.

Using contextual fear conditioning, a robust hippocampus-dependent task (Kim and Fanselow, 1992) that relies on stimuli and behavioral outputs distinct from the water maze permitted an independent test of the hypothesis that the enhanced spatial learning in $\mathrm{H}$-ras ${ }^{G 12 V}$ mice results from a change in hippocampal function. After training with three footshocks, mice were returned to the same context $24 \mathrm{~h}$ later to assess long-term memory, and freezing behavior was recorded using automated procedures (Anagnostaras et al., 2000). H-ras ${ }^{G 12 V}$ mice showed significantly more contextual learning during the $24 \mathrm{~h}$ test compared with their WT littermates $\left(F_{(1,14)}=9.4 ; p<0.01\right)$, whereas baseline freezing before training was normal (Fig. $9 D)\left(F_{(1,14)}=0.23 ; p=0.64\right)$. We also examined the suppression of activity as an additional measure of conditioned fear (Anagnostaras et al., 2000). Indeed, $\mathrm{H}$-ras ${ }^{G 12 V}$ mice also showed an enhanced suppression ratio consistent with increased fear of the context (WT, $0.21 \pm 0.02 ; \mathrm{H}_{\text {-ras }}{ }^{G 12 V}, 0.13 \pm 0.01$; $\left.F_{(1,14)}=9.9 ; p<0.01\right)$. Importantly, the enhancement in fear conditioning was not attributable to differences in footshock sensitivity
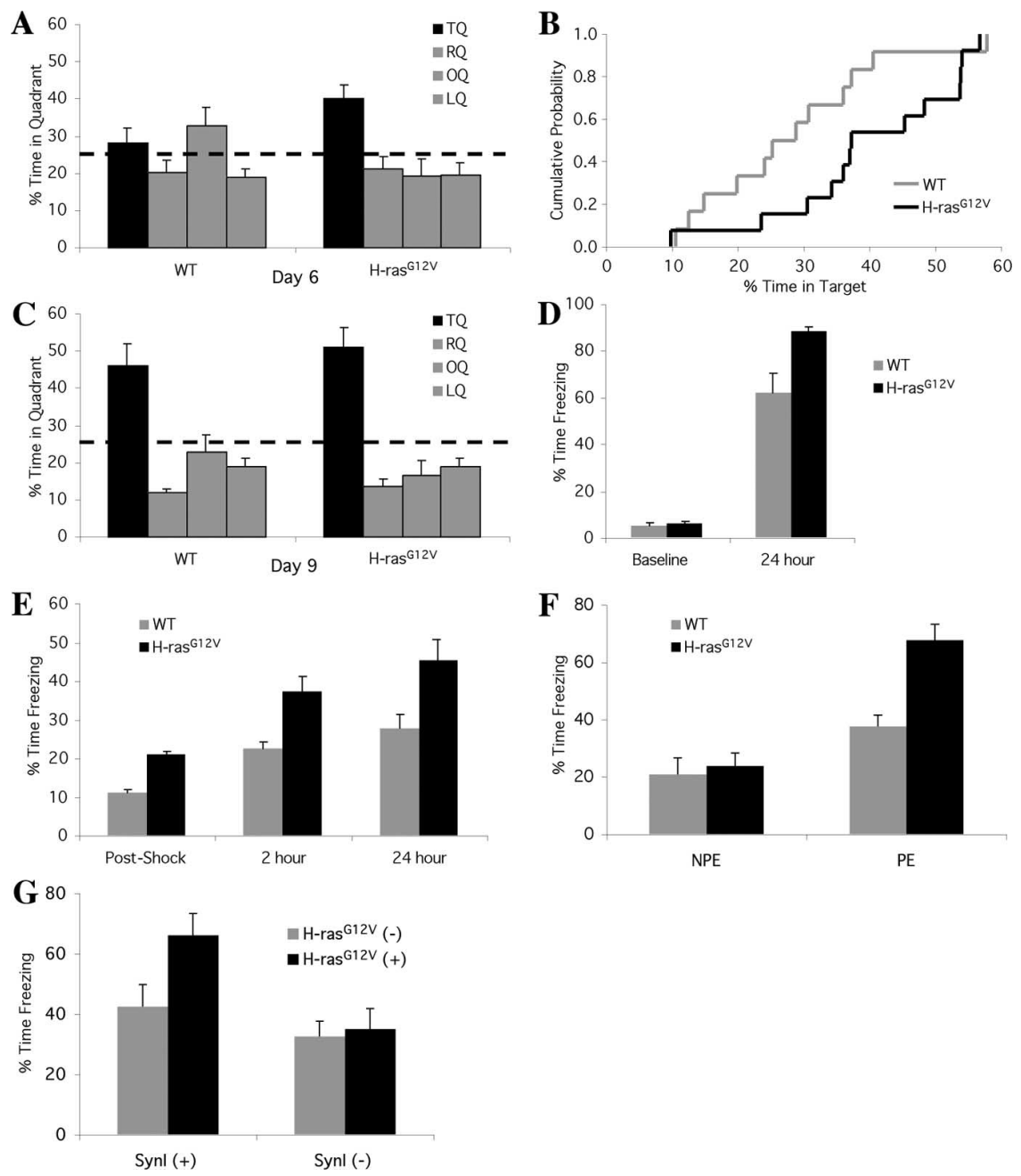

Figure 9. Enhanced learning of hippocampus-dependent tasks in $H$-ras ${ }^{G 12 V}$ mice is mediated by synapsin I. $\boldsymbol{A}-\boldsymbol{C}, \mathrm{WT}(n=12)$ and $\mathrm{H}_{-\mathrm{ras}^{G 12 V}}(n=13)$ littermates were trained in the Morris water maze for $9 \mathrm{~d}$. A probe trial conducted after the sixth day of training revealed that $\mathrm{H}$-ras ${ }^{G 12 V}$ mice searched selectively in the target quadrant, but their WT littermates showed no preference (A). Dashed line at $25 \%$ time quadrant represents random searching. The cumulative probability distribution of target quadrant occupancy time during the probe trial demonstrates that $\mathrm{H}-\mathrm{ras}^{\mathrm{G}}{ }^{\mathrm{V} V}$ mice are more highly selective during searching than their WT littermates $(\boldsymbol{B})$. During a probe trial performed after the ninth training day, WT and $H$-ras ${ }^{G 12 V}$ mice showed similar target quadrant selectivity (C). TQ, Target quadrant; RQ, adjacent right quadrant; $0 Q$, opposite quadrant; LQ, adjacent left quadrant. D, E, Shortand long-term memory of $\mathrm{H}$-ras ${ }^{G 12 V}$ mice were evaluated using contextual fear conditioning. Learning was enhanced in $\mathrm{H}$-ras ${ }^{G 12 V}$ mice during a $24 \mathrm{~h}$ long-term memory test for contextual fear conditioning with three footshocks in the absence of any observed changes in baseline freezing (WT, $n=8 ; \mathrm{H}$-ras $\left.^{G 12 \mathrm{~V}}, n=8\right)(\boldsymbol{D})$. Conditional freezing was increased in $\mathrm{H}_{\text {-ras }}{ }^{G 12 \mathrm{~V}}$ mice immediately after shock (WT, $\left.n=23 ; H_{-r_{a s}{ }^{G 12 V}}, n=21\right)$ and $2 \mathrm{~h}\left(\mathrm{WT}, n=8 ; H-\right.$ ras $\left.^{G 12 V}, n=10\right)$ and $24 \mathrm{~h}\left(\mathrm{WT}, n=15 ; H\right.$-ras $\left.{ }^{G 12 V}, n=11\right)$ after training with a single footshock $(\boldsymbol{E})$. $\boldsymbol{F}$, Three minute context preexposure, $24 \mathrm{~h}$ before receiving immediate shock training, resulted in enhanced conditional fear for $H$-ras ${ }^{G 12 V}(n=10)$ compared with WT mice $(n=13)$. There was no difference in conditional freezing between WT $(n=11)$ and $H_{-r a s}{ }^{G 12 V}(n=13)$ mice after immediate shock training in the absence of preexposure. G, Enhanced learning in $\mathrm{H}$-ras ${ }^{G 12 \mathrm{~V}}$ mice is dependent on synapsin I. Contextual fear conditioning using three footshocks showed that, in the background of the wild-type synapsin I allele, $[\operatorname{Syn} /(+)], H$-ras ${ }^{G 12 V}(+)$ mice $(n=10)$ showed significantly more conditioned fear than $H-$ ras $^{G 12 V}(-)$ littermates $(n=11)$. In contrast, deletion of synapsin I [SynI( $)$ ] pre-

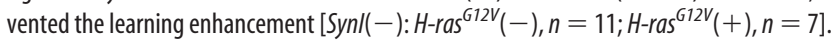

because unconditioned responding during footshock was equivalent for $H$-ras ${ }^{G 12 V}(38.4 \pm 7.1 \mathrm{~cm} / \mathrm{s})$ and WT $(40.6 \pm 4.9 \mathrm{~cm} / \mathrm{s})$ littermates $\left(F_{(1,14)}=0.17 ; p=0.69\right)$. Short-term memory was assessed after training with a single footshock to avoid saturating the conditioned response. Separate groups of mice were used to independently examine freezing at 2 and $24 \mathrm{~h}$ after training. $\mathrm{H}$-ras ${ }^{G 12 V}$ mice showed significantly more freezing than their WT littermates immediately after shock $\left(F_{(1,42)}=5.1 ; p<0.05\right)$ as well as $2 \mathrm{~h}\left(F_{(1,16)}=4.6\right.$; $p<0.05)$ and $24 \mathrm{~h}\left(F_{(1,24)}=6.6 ; p<0.05\right)$ after training (Fig. $\left.9 E\right)$.

The formation of contextual fear memory requires an animal 
to create a hippocampus-dependent representation of the training environment (Kim and Fanselow, 1992; Rudy et al., 2002). Significantly decreasing the placement-to-shock interval during contextual conditioning, so that the animal is shocked immediately after entering the training chamber, results in a concomitant decrease in the strength of the resulting fear memory, known as the immediate shock deficit (ISD). This deficit is thought to arise from an inability to form an adequate representation of the training context (Fanselow, 1990; Frankland et al., 2004). Consistent with this interpretation, preexposure (PE) to the training context can rescue the ISD (Fanselow, 1990) and has been shown to require protein synthesis within the hippocampus (Rudy et al., 2002; Frankland et al., 2004). If the learning enhancements seen in $\mathrm{H}$-ras ${ }^{G 12 V}$ mice result from an alteration in the processing of contextual and spatial information in the hippocampus, the amount of PE sufficient to rescue the ISD should be decreased in $H$-ras ${ }^{G 12 V}$ mice compared with their WT littermates. Therefore, we used a 3 min PE to the training context, which is insufficient to rescue the ISD in WT mice (Frankland et al., 2004). Animals of each genotype received either no preexposure training (NPE) or context PE $24 \mathrm{~h}$ before receiving an immediate footshock. Conditioned fear was assessed $24 \mathrm{~h}$ after immediate shock training. There was a significant interaction of genotype with preexposure on conditioned fear (Fig. $9 F)\left(F_{(1,43)}=7.6 ; p<0.01\right)$. In groups receiving $\mathrm{PE}$ training, $\mathrm{H}$-ras ${ }^{G 12 V}$ mice showed a significant increase in freezing compared with WT mice (PLSD, $p<0.001$ ). Importantly, $\mathrm{H}$-ras ${ }^{G 12 V}$ and WT mice receiving NPE showed similar freezing after immediate shock training, indicating that increased freezing in $\mathrm{H}$-ras ${ }^{G 12 \mathrm{~V}}$ mice is dependent on an involvement of the hippocampus in the formation of contextual representations during fear conditioning (PLSD, $p=0.69$ ).

\section{Learning enhancement is mediated by synapsin I}

Our data suggests a model in which presynaptic activation of $\mathrm{H}$-ras/ERK/synapsin I signaling during experience-dependent plasticity functions to modulate learning. Therefore, we hypothesized that, similar to the facilitation in presynaptic plasticity, the hippocampus-dependent learning enhancement displayed by $H$-ras ${ }^{G 12 V}$ mice should require synapsin I. To examine whether synapsin I is required for the enhancement in learning, we crossed synapsin I knock-out mice (Rosahl et al., 1993) with $\mathrm{H}$-ras ${ }^{G 12 V}$ transgenics. Contextual fear conditioning was performed using three footshocks, and long-term memory was assessed in the same context $24 \mathrm{~h}$ later in all four genotypic groups. Indeed, there was a significant effect of genotype on conditioned fear (Fig. 9G) $\left(F_{(3,35)}=5.3 ; p<0.01\right)$. As expected, $H$-ras ${ }^{G 12 V}(+)$ mice showed significantly more freezing than $\mathrm{H}$-ras ${ }^{G 12 V}(-)$ littermates in the presence of the wild-type synapsin I allele (PLSD, $p<0.05)$. However in the background of the synapsin I knockout allele, $H$-ras ${ }^{G 12 V}(+)$ and $H$-ras ${ }^{G 12 V}(-)$ mice showed equivalent responses (PLSD, $p=0.81$ ), demonstrating that the $\mathrm{H}$-ras ${ }^{\mathrm{G} 12 \mathrm{~V}}$-mediated learning enhancement requires synapsin $\mathrm{I}$. Together, these results strongly argue that integrity of the presynaptic $\mathrm{H}$-ras/ERK/synapsin I signaling pathway is necessary for the enhanced synaptic and behavioral plasticity observed in $H$-ras ${ }^{G 12 V}$ mice.

\section{Discussion}

In invertebrate systems, coordinated plasticity between presynaptic and postsynaptic neurons has been shown to contribute directly to learning (Antonov et al., 2003; Roberts and Glanzman, 2003). Genetic and pharmacologic studies in mammalian systems have provided considerable evidence that postsynaptic pro- cesses required for synaptic plasticity are critical for learning and memory (Martin et al., 2000). However, few studies have identified presynaptic mechanisms necessary for mammalian cognition (Powell et al., 2004). The present study is the first example that targeted manipulation of biochemical signaling in axon terminals can enhance learning and synaptic plasticity in mammals. In addition, our data support the long-standing hypothesis that short-term presynaptic plasticity influences the induction of LTP (Dobrunz and Stevens, 1999). Specifically, our results demonstrate a novel cellular function of $\mathrm{H}$-ras/ERK signaling: by regulating the density of docked vesicles via ERK-dependent phosphorylation of synapsin I, experience-dependent changes in the activity of presynaptic H-ras modulate the induction of longterm synaptic plasticity underlying learning through a frequencydependent facilitation of neurotransmitter release.

Our confocal and electron microscopy studies demonstrate that $\mathrm{H}$-ras is abundantly localized to axon terminals, with limited expression in postsynaptic spines. Although under certain conditions p $21^{\text {Ras }}$ appears to be involved in NMDA-dependent postsynaptic plasticity (Husi et al., 2000; Manabe et al., 2000; Zhu et al., 2002), our transgenic results were not caused by postsynaptic mechanisms. Long-term potentiation induced by both theta-frequency extracellular stimulation and associative wholecell pairing are dependent on ERK signaling in dendrites downstream of the postsynaptic NMDA receptor (Winder et al., 1999; Watanabe et al., 2002). Consistent with intact postsynaptic ERK signaling, $5 \mathrm{~Hz}$ extracellular and $0.5 \mathrm{~Hz}$ associative LTP were normal in $\mathrm{H}$-ras ${ }^{G 12 V}$ mice. In contrast, LTP was increased using NMDA-dependent theta-burst and $100 \mathrm{~Hz}$ stimulation protocols, which cause significant short-term presynaptic vesicle depletion. Importantly, the increases in LTP induction observed in $H$-ras ${ }^{G 12 V}$ mice were associated with similar increases in shortterm presynaptic plasticity, highlighted by the frequencydependent enhancement of PPF. In particular, our electrophysiologic analyses of short-term plasticity were conducted in the presence of APV and picrotoxin, ensuring that the observed changes truly reflected a modulation of neurotransmitter release, not attributable to alterations in postsynaptic or inhibitory plasticity. The demonstration of enhanced neurotransmitter release during high-frequency stimulation is further supported by the associated increase in docked neurotransmitter vesicles at presynaptic active zones of $\mathrm{H}$-ras ${ }^{G 12 V}$ mice and an increased frequency but not amplitude of mEPSCs. Interestingly, although PPF, STP, mEPSC frequency, and the density of docked vesicles were all increased, baseline synaptic transmission was maintained, likely mediated through presynaptic homeostatic plasticity (Davis and Goodman, 1998; Jones et al., 1998; Daniels et al., 2004; Piedras-Renteria et al., 2004). Together, these data suggest that the LTP enhancements in $\mathrm{H}$-ras ${ }^{G 12 V}$ mice do not result from changes in postsynaptic plasticity but rather from a frequencydependent facilitation of short-term presynaptic plasticity leading to increased neurotransmitter release specifically during high-frequency LTP induction.

Furthermore, we have used a genetic approach to evaluate the hypothesis that the ERK-dependent phosphorylation of synapsin I represents a critical presynaptic mechanism responsible for mediating $\mathrm{H}$-ras-dependent changes in behavioral and synaptic plasticity. By crossing $H$-ras ${ }^{G 12 V}$ and synapsin $I^{-1-}$ mice, we have confirmed the requirement for the presynaptic target of ERK1/2, synapsin I, in mediating the enhancements of presynaptic plasticity, LTP, and learning observed in $\mathrm{H}$-ras ${ }^{G 12 V}$ mice. Interestingly, although we show that enhancing synapsin I function leads to LTP and learning enhancements, our present data are consis- 
tent with previous studies demonstrating that synapsin I knockout mice have seemingly normal LTP and learning (Rosahl et al., 1993; Silva et al., 1996), reflecting a functional redundancy between synapsin I and II (Rosahl et al., 1995; Silva et al., 1996). Accordingly, synapsin I/II double mutants show synaptic and learning deficits absent in either single gene mutant (Rosahl et al., 1995; Silva et al., 1996). Consistent with these findings, both synapsin I and II are required for an ERK-dependent facilitation of synaptosomal neurotransmitter release (Jovanovic et al., 2000).

Under normal physiologic conditions in WT mice, we have performed multiple experiments supporting the presence in vivo of a dynamic and experience-dependent endogenous presynaptic $\mathrm{H}$-ras/ERK/synapsin I signaling pathway. In two different genetic backgrounds of WT mice, we demonstrate that ERK-dependent synapsin I phosphorylation occurs specifically during hippocampus-dependent learning but not after unconditioned shock. In addition, the expression level and subcellular localization of $\mathrm{H}$-ras ${ }^{\mathrm{G} 12 \mathrm{~V}}$ is equivalent to endogenous H-ras, demonstrating that the mechanisms underlying the learning enhancement in $H$-ras ${ }^{G 12 V}$ mice are physiologically relevant. Consistent with an important endogenous function for ERK-dependent phosphorylation of synapsin I in regulating presynaptic neurotransmitter release dynamics, we also showed that MEK/ERK inhibition selectively decreases mEPSC frequency but not amplitude in normal WT mice and completely abolishes the increased mEPSC frequency in $\mathrm{H}$-ras ${ }^{G 12 V}$ mice. Importantly, the timescale of MEK/ERK inhibition (15-20 min) during the mEPSC recordings makes a transcription/translation mechanism very unlikely, while supporting a posttranslational mechanism such as the inhibition of ERK-dependent synapsin I phosphorylation at presynaptic sites.

How might the facilitation of neurotransmitter release during high-frequency stimulation mediate an enhancement in spatial learning? Salient information in hippocampal CA1 neuronal ensembles is thought to be encoded during synchronous highfrequency spike bursts contrasting against a homeostatic background of low-frequency activity (Otto et al., 1991; Lisman, 1997). The present findings demonstrate that the H-ras ${ }^{\mathrm{G} 12 \mathrm{~V}} \mathrm{mu}-$ tation specifically enhances release during patterns of highfrequency synaptic activity typically observed during hippocampus-dependent learning (Otto et al., 1991; Lisman, 1997), while leaving basal synaptic transmission unchanged. Thus, one parsimonious model for the learning enhancements in $H$-ras ${ }^{G 12 V}$ mice is an increased fidelity of synaptic transmission during hippocampus-dependent encoding of salient stimuli.

How is the presynaptic $\mathrm{H}$-ras/ERK/synapsin I signaling pathway recruited during learning? A potent presynaptic activator of p $21^{\text {Ras }}$ is the brain-derived neurotrophic factor (BDNF) receptor TrkB. Several genetic and pharmacologic studies have shown that $\mathrm{BDNF} /$ TrkB signaling can modulate presynaptic function and learning (Xu et al., 2000; Tyler et al., 2002; Zhang and Poo, 2002). Consistent with our results, BDNF has been shown to increase synaptosomal glutamate release through the ERK-dependent phosphorylation of synapsin I (Jovanovic et al., 2000). In addition, treatment of organotypic hippocampal slices with BDNF results in an increase in the density of docked vesicles (Tyler and Pozzo-Miller, 2001). Similar studies performed in neonatal hippocampal slices demonstrated a BDNF-specific and ERKdependent attenuation of synaptic fatigue selectively during high-frequency stimulation (Gottschalk et al., 1998, 1999). Finally, the LTP enhancements observed in $\mathrm{H}$-ras ${ }^{G 12 \mathrm{~V}}$ mice are consistent with a recent study demonstrating that BDNF modu- lates presynaptic plasticity at the hippocampal Schaffer collateral-CA1 synapse in vivo (Zakharenko et al., 2003).

The studies presented here represent a first step toward understanding how presynaptic signaling modulates learning and memory in mammals. Together with previous findings in invertebrate models, these results demonstrate that the modulation of presynaptic function is an evolutionarily conserved mechanism for learning and memory.

\section{References}

Adams JP, Sweatt JD (2002) Molecular psychology: roles for the ERK MAP kinase cascade in memory. Annu Rev Pharmacol Toxicol 42:135-163.

Adams JP, Anderson AE, Varga AW, Dineley KT, Cook RG, Pfaffinger PJ, Sweatt JD (2000) The A-type potassium channel Kv4.2 is a substrate for the mitogen-activated protein kinase ERK. J Neurochem 75:2277-2287.

Anagnostaras SG, Josselyn SA, Frankland PW, Silva AJ (2000) Computerassisted behavioral assessment of Pavlovian fear conditioning in mice. Learn Mem 7:58-72.

Antonov I, Antonova I, Kandel ER, Hawkins RD (2003) Activity-dependent presynaptic facilitation and hebbian LTP are both required and interact during classical conditioning in Aplysia. Neuron 37:135-147.

Atkins CM, Selcher JC, Petraitis J, Trzaskos J, Sweatt J (1998) The MAPK cascade is required for mammalian associative learning. Nat Neurosci 1:602-609.

Bahler M, Greengard P (1987) Synapsin I bundles F-actin in a phosphorylation-dependent manner. Nature 326:704-707.

Benfenati F, Bahler M, Jahn R, Greengard P (1989) Interactions of synapsin I with small synaptic vesicles: distinct sites in synapsin I bind to vesicle phospholipids and vesicle proteins. J Cell Biol 108:1863-1872.

Benfenati F, Valtorta F, Rubenstein JL, Gorelick FS, Greengard P, Czernik AJ (1992) Synaptic vesicle-associated $\mathrm{Ca}^{2+} /$ calmodulin-dependent protein kinase II is a binding protein for synapsin I. Nature 359:417-420.

Brager DH, Capogna M, Thompson SM (2002) Short-term synaptic plasticity, simulation of nerve terminal dynamics, and the effects of protein kinase C activation in rat hippocampus. J Physiol (Lond) 541:545-559.

Brandeis R, Brandys Y, Yehuda S (1989) The use of the Morris water maze in the study of memory and learning. Int J Neurosci 48:29-69.

Burrell BD, Sahley CL (2001) Learning in simple systems. Curr Opin Neurobiol 11:757-764.

Chi P, Greengard P, Ryan TA (2003) Synaptic vesicle mobilization is regulated by distinct synapsin I phosphorylation pathways at different frequencies. Neuron 38:69-78.

Chin J, Angers A, Cleary LJ, Eskin A, Byrne JH (2002) Transforming growth factor $\beta$-1 alters synapsin distribution and modulates synaptic depression in Aplysia. J Neurosci 22:1-6.

Costa RM, Yang T, Huynh DP, Pulst SM, Viskochil DH, Silva AJ, Brannan CI (2001) Learning deficits, but normal development and tumor predisposition, in mice lacking exon 23a of Nf1. Nat Genet 27:399-405.

Daniels RW, Collins CA, Gelfand MV, Dant J, Brooks ES, Krantz DE, DiAntonio A (2004) Increased expression of the Drosophila vesicular glutamate transporter leads to excess glutamate release and a compensatory decrease in quantal content. J Neurosci 24:10466-10474.

Davis GW, Goodman CS (1998) Synapse-specific control of synaptic efficacy at the terminals of a single neuron. Nature 392:82-86.

Dickinson-Nelson A, Reese TS (1983) Structural changes during transmitter release at synapses in the frog sympathetic ganglion. J Neurosci 3:42-52.

Dobrunz LE, Stevens CF (1997) Heterogeneity of release probability, facilitation, and depletion at central synapses. Neuron 18:995-1008.

Dobrunz LE, Stevens CF (1999) Response of hippocampal synapses to natural stimulation patterns. Neuron 22:157-166.

Dobrunz LE, Huang EP, Stevens CF (1997) Very short-term plasticity in hippocampal synapses. Proc Natl Acad Sci USA 94:14843-14847.

Elgersma Y, Fedorov N, Ikonen S, Choi E, Elgersma M, Carvalho O, Giese K, Silva A (2002) Inhibitory autophosphorylation of CaMKII controls PSD association, plasticity and learning. Neuron 36:493-505.

English JD, Sweatt JD (1996) Activation of p42 mitogen-activated protein kinase in hippocampal long term potentiation. J Biol Chem 271:24329-24332.

Fanselow MS (1990) Factors governing one-trial contextual conditioning. Anim Learn Behav 18:264-270. 
Frankland P, O'Brien C, Ohno M, Kirkwood A, Silva A (2001) AlphaCaMKII-dependent plasticity in the cortex is required for permanent memory. Nature 411:309-313.

Frankland PW, Josselyn SA, Anagnostaras SG, Kogan JH, Takahashi E, Silva AJ (2004) Consolidation of CS and US representations in associative fear conditioning. Hippocampus 14:557-569.

Frick A, Magee J, Johnston D (2004) LTP is accompanied by an enhanced local excitability of pyramidal neuron dendrites. Nat Neurosci 7:126-135.

Gartner U, Alpar A, Seeger G, Heumann R, Arendt T (2004) Enhanced Ras activity in pyramidal neurons induces cellular hypertrophy and changes in afferent and intrinsic connectivity in synRas mice. Int J Dev Neurosci 22:165-173.

Gottschalk W, Pozzo-Miller LD, Figurov A, Lu B (1998) Presynaptic modulation of synaptic transmission and plasticity by brain-derived neurotrophic factor in the developing hippocampus. J Neurosci 18:6830-6839.

Gottschalk WA, Jiang H, Tartaglia N, Feng L, Figurov A, Lu B (1999) Signaling mechanisms mediating BDNF modulation of synaptic plasticity in the hippocampus. Learn Mem 6:243-256.

Heumann R, Goemans C, Bartsch D, Lingenhohl K, Waldmeier PC, Hengerer B, Allegrini PR, Schellander K, Wagner EF, Arendt T, Kamdem RH, ObstPernberg K, Narz F, Wahle P, Berns H (2000) Transgenic activation of Ras in neurons promotes hypertrophy and protects from lesion-induced degeneration. J Cell Biol 151:1537-1548.

Hilfiker S, Pieribone VA, Czernik AJ, Kao HT, Augustine GJ, Greengard P (1999) Synapsins as regulators of neurotransmitter release. Philos Trans R Soc Lond B Biol Sci 354:269-279.

Humeau Y, Doussau F, Vitiello F, Greengard P, Benfenati F, Poulain B (2001) Synapsin controls both reserve and releasable synaptic vesicle pools during neuronal activity and short-term plasticity in Aplysia. J Neurosci 21:4195-4206.

Husi H, Ward MA, Choudhary JS, Blackstock WP, Grant SG (2000) Proteomic analysis of NMDA receptor-adhesion protein signaling complexes. Nat Neurosci 3:661-669.

Iida N, Namikawa K, Kiyama H, Ueno H, Nakamura S, Hattori S (2001) Requirement of Ras for the activation of mitogen-activated protein kinase by calcium influx, cAMP, and neurotrophin in hippocampal neurons. J Neurosci 21:6459-6466.

Jaarsma D, Rognoni F, van Duijn W, Verspaget HW, Haasdijk ED, Holstege JC (2001) CuZn superoxide dismutase (SOD1) accumulates in vacuolated mitochondria in transgenic mice expressing amyotrophic lateral sclerosis-linked SOD1 mutations. Acta Neuropathol (Berl) 102:293-305.

Jones SR, Gainetdinov RR, Jaber M, Giros B, Wightman RM, Caron MG (1998) Profound neuronal plasticity in response to inactivation of the dopamine transporter. Proc Natl Acad Sci USA 95:4029-4034.

Jovanovic JN, Benfenati F, Siow YL, Sihra TS, Sanghera JS, Pelech SL, Greengard P, Czernik AJ (1996) Neurotrophins stimulate phosphorylation of synapsin I by MAP kinase and regulate synapsin I-actin interactions. Proc Natl Acad Sci USA 93:3679-3683.

Jovanovic JN, Czernik AJ, Fienberg AA, Greengard P, Sihra TS (2000) Synapsins as mediators of BDNF-enhanced neurotransmitter release. Nat Neurosci 3:323-329.

Jovanovic JN, Sihra TS, Nairn AC, Hemmings Jr HC, Greengard P, Czernik AJ (2001) Opposing changes in phosphorylation of specific sites in synapsin I during $\mathrm{Ca}^{2+}$-dependent glutamate release in isolated nerve terminals. J Neurosci 21:7944-7953.

Kim JJ, Fanselow MS (1992) Modality-specific retrograde amnesia of fear. Science 256:675-677.

Koh YH, Ruiz-Canada C, Gorczyca M, Budnik V (2002) The Ras1-mitogenactivated protein kinase signal transduction pathway regulates synaptic plasticity through fasciclin II-mediated cell adhesion. J Neurosci 22:2496-2504.

Komiyama NH, Watabe AM, Carlisle HJ, Porter K, Charlesworth P, Monti J, Strathdee DJ, O'Carroll CM, Martin SJ, Morris RG, O’Dell TJ, Grant SG (2002) SynGAP regulates ERK/MAPK signaling, synaptic plasticity, and learning in the complex with postsynaptic density 95 and NMDA receptor. J Neurosci 22:9721-9732.

Larson J, Wong D, Lynch G (1986) Patterned stimulation at the theta frequency is optimal for the induction of hippocampal long-term potentiation. Brain Res 368:347-350.

Li L, Chin LS, Shupliakov O, Brodin L, Sihra TS, Hvalby O, Jensen V, Zheng D, McNamara JO, Greengard P, Andersen P (1995) Impairment of synaptic vesicle clustering and of synaptic transmission, and increased sei- zure propensity, in synapsin I-deficient mice. Proc Natl Acad Sci USA 92:9235-9239.

Lisman JE (1997) Bursts as a unit of neural information: making unreliable synapses reliable. Trends Neurosci 20:38-43.

Malenka RC, Nicoll RA (1999) Long-term potentiation-a decade of progress? Science 285:1870-1874.

Manabe T, Aiba A, Yamada A, Ichise T, Sakagami H, Kondo H, Katsuki M (2000) Regulation of long-term potentiation by $H$-ras through NMDA receptor phosphorylation. J Neurosci 20:2504-2511.

Martin KC, Michael D, Rose JC, Barad M, Casadio A, Zhu H, Kandel ER (1997) MAP kinase translocates into the nucleus of the presynaptic cell and is required for long-term facilitation in Aplysia. Neuron 18:899-912.

Martin SJ, Grimwood PD, Morris RG (2000) Synaptic plasticity and memory: an evaluation of the hypothesis. Annu Rev Neurosci 23:649-711.

Mayford M, Wang J, Kandel ER, O'Dell TJ (1995) CaMKII regulates the frequency-response function of hippocampal synapses for the production of both LTD and LTP. Cell 81:891-904.

Morris RG, Garrud P, Rawlins JN, O’Keefe J (1982) Place navigation impaired in rats with hippocampal lesions. Nature 297:681-683.

Otto T, Eichenbaum H, Wiener SI, Wible CG (1991) Learning-related patterns of CAl spike trains parallel stimulation parameters optimal for inducing hippocampal long-term potentiation. Hippocampus 1:181-192.

Phend KD, Rustioni A, Weinberg RJ (1995) An osmium-free method of epon embedment that preserves both ultrastructure and antigenicity for post-embedding immunocytochemistry. J Histochem Cytochem 43:283-292.

Piedras-Renteria ES, Pyle JL, Diehn M, Glickfeld LL, Harata NC, Cao Y, Kavalali ET, Brown PO, Tsien RW (2004) Presynaptic homeostasis at CNS nerve terminals compensates for lack of a key $\mathrm{Ca}^{2+}$ entry pathway. Proc Natl Acad Sci USA 101:3609-3614.

Pieribone VA, Shupliakov O, Brodin L, Hilfiker-Rothenfluh S, Czernik AJ, Greengard P (1995) Distinct pools of synaptic vesicles in neurotransmitter release. Nature 375:493-497.

Powell CM, Schoch S, Monteggia L, Barrot M, Matos MF, Feldmann N, Sudhof TC, Nestler EJ (2004) The presynaptic active zone protein RIM1 alpha is critical for normal learning and memory. Neuron 42:143-153.

Pozzo-Miller LD, Gottschalk W, Zhang L, McDermott K, Du J, Gopalakrishnan R, Oho C, Sheng ZH, Lu B (1999) Impairments in high-frequency transmission, synaptic vesicle docking, and synaptic protein distribution in the hippocampus of BDNF knock-out mice. J Neurosci 19:4972-4983.

Roberts AC, Glanzman DL (2003) Learning in Aplysia: looking at synaptic plasticity from both sides. Trends Neurosci 26:662-670.

Rosahl TW, Geppert M, Spillane D, Herz J, Hammer RE, Malenka RC, Sudhof TC (1993) Short-term synaptic plasticity is altered in mice lacking synapsin I. Cell 75:661-670.

Rosahl TW, Spillane D, Missler M, Herz J, Selig DK, Wolff JR, Hammer RE, Malenka RC, Sudhof TC (1995) Essential functions of synapsins I and II in synaptic vesicle regulation. Nature 375:488-493.

Rosen LB, Ginty DD, Weber MJ, Greenberg ME (1994) Membrane depolarization and calcium influx stimulate MEK and MAP kinase via activation of Ras. Neuron 12:1207-1221.

Rudy JW, Barrientos RM, O'Reilly RC (2002) Hippocampal formation supports conditioning to memory of a context. Behav Neurosci 116:530-538.

Schiebler W, Jahn R, Doucet JP, Rothlein J, Greengard P (1986) Characterization of synapsin I binding to small synaptic vesicles. J Biol Chem 261:8383-8390.

Schikorski T, Stevens CF (1997) Quantitative ultrastructural analysis of hippocampal excitatory synapses. J Neurosci 17:5858-5867.

Schikorski T, Stevens CF (2001) Morphological correlates of functionally defined synaptic vesicle populations. Nat Neurosci 4:391-395.

Schnell E, Nicoll RA (2001) Hippocampal synaptic transmission and plasticity are preserved in myosin Va mutant mice. J Neurophysiol 85:1498-1501.

Selcher JC, Weeber EJ, Christian J, Nekrasova T, Landreth GE, Sweatt JD (2003) A role for ERK MAP kinase in physiologic temporal integration in hippocampal area CA1. Learn Mem 10:26-39.

Sharma SK, Sherff CM, Shobe J, Bagnall MW, Sutton MA, Carew TJ (2003) Differential role of mitogen-activated protein kinase in three distinct phases of memory for sensitization in Aplysia. J Neurosci 23:3899-3907. Silva AJ, Rosahl TW, Chapman PF, Marowitz Z, Friedman E, Frankland PW, 
Cestari V, Cioffi D, Sudhof TC, Bourtchuladze R (1996) Impaired learning in mice with abnormal short-lived plasticity. Curr Biol 6:1509-1518.

Tsodyks MV, Markram H (1997) The neural code between neocortical pyramidal neurons depends on neurotransmitter release probability. Proc Natl Acad Sci USA 94:719-723.

Tyler WJ, Pozzo-Miller LD (2001) BDNF enhances quantal neurotransmitter release and increases the number of docked vesicles at the active zones of hippocampal excitatory synapses. J Neurosci 21:4249-4258.

Tyler WJ, Alonso M, Bramham CR, Pozzo-Miller LD (2002) From acquisition to consolidation: on the role of brain-derived neurotrophic factor signaling in hippocampal-dependent learning. Learn Mem 9:224-237.

Varela JA, Sen K, Gibson J, Fost J, Abbott LF, Nelson SB (1997) A quantitative description of short-term plasticity at excitatory synapses in layer $2 / 3$ of rat primary visual cortex. J Neurosci 17:7926-7940.

Watanabe S, Hoffman DA, Migliore M, Johnston D (2002) Dendritic K ${ }^{+}$ channels contribute to spike-timing dependent long-term potentiation in hippocampal pyramidal neurons. Proc Natl Acad Sci USA 99:8366-8371.

Winder DG, Martin KC, Muzzio IA, Rohrer D, Chruscinski A, Kobilka B, Kandel ER (1999) ERK plays a regulatory role in induction of LTP by theta frequency stimulation and its modulation by beta-adrenergic receptors. Neuron 24:715-726.

Wisden W, Errington ML, Williams S, Dunnett SB, Waters C, Hitchcock D,
Evan G, Bliss TVP, Hunt SP (1990) Differential expression of immediate early genes in the hippocampus and spinal cord. Neuron 4:603-614.

Xu B, Gottschalk W, Chow A, Wilson RI, Schnell E, Zang K, Wang D, Nicoll RA, Lu B, Reichardt LF (2000) The role of brain-derived neurotrophic factor receptors in the mature hippocampus: modulation of long-term potentiation through a presynaptic mechanism involving TrkB. J Neurosci 20:6888-6897.

Yuan LL, Adams JP, Swank M, Sweatt JD, Johnston D (2002) Protein kinase modulation of dendritic $\mathrm{K}^{+}$channels in hippocampus involves a mitogen-activated protein kinase pathway. J Neurosci 22:4860-4868.

Zakharenko SS, Patterson SL, Dragatsis I, Zeitlin SO, Siegelbaum SA, Kandel ER, Morozov A (2003) Presynaptic BDNF required for a presynaptic but not postsynaptic component of LTP at hippocampal CA1-CA3 synapses. Neuron 39:975-990.

Zhang X, Poo MM (2002) Localized synaptic potentiation by BDNF requires local protein synthesis in the developing axon. Neuron 36:675-688.

Zhu JJ, Qin Y, Zhao M, Van Aelst L, Malinow R (2002) Ras and Rap control AMPA receptor trafficking during synaptic plasticity. Cell 110:443-455.

Zucker RS, Regehr WG (2002) Short-term synaptic plasticity. Annu Rev Physiol 64:355-405. 